\title{
Initial Study of Coal Pretreatment and Coprocessing
}

\section{Topical Report}

\author{
M. Vaillancourt \\ T.F. Turner \\ L.J. Fahy
}

September 1991

Work Performed Under Contract No.: DE-FC21-86MC11076

For

U.S. Department of Energy

Office of Fossil Energy

Morgantown Energy Technology Center

Morgantown, West Virginia

By

University of Wyoming

Western Research Institute

Laramie, Wyoming 


\section{DISCLAIMER}

This report was prepared as an account of work sponsored by an agency of the United States Government. Neither the United States Government nor any agency thereof, nor any of their employees makes any warranty, express or implied, or assumes any legal liability or responsibility for the accuracy, completeness or usefulness of any information, apparatus, product, or process disclosed, or represents that its use would not infringe privately owned rights. Reference herein to any specific commercial product, process, or service by trade name, trademark, manufacturer, or otherwise, does not necessarily constitute or imply its endorsement, recommendation, or favoring by the United States Government or any agency thereof. The views and opinions of authors expressed herein do not necessarily state or reflect those of the United States Government or any agency thereof.

This report has been reproduced directly from the best available copy.

Available to DOE and DOE contractors from the Office of Scientific and Technical Information, P.O. Box 62, Oak Ridge, TN 37831; prices available from (615)576-8401, FTS 626-8401.

Available to the public from the National Technical Information Service, U.S. Department of Commerce, 5285 Port Royal Rd., Springfield, VA 22161. 


\title{
Initial Study of Coal Pretreatment and Coprocessing
}

\author{
Topical Report
}
M. Vaillancourt
T.F. Turner
L.J. Fahy

Work Performed Under Contract No.: DE-FC21-86MC11076

\author{
For \\ U.S. Department of Energy \\ Office of Fossil Energy \\ Morgantown Energy Technology Center \\ P.O. Box 880 \\ Morgantown, West Virginia 26507-0880 \\ By \\ University of Wyoming \\ Western Research Institute \\ P.O. Box 3395 \\ University Station \\ Laramie, Wyoming 82071
}

September 1991 
IIST OF FIGURES $\ldots \ldots \ldots \ldots \ldots \ldots \ldots \ldots \ldots \ldots \ldots \ldots \ldots \ldots \ldots \ldots \ldots \ldots \ldots \ldots$

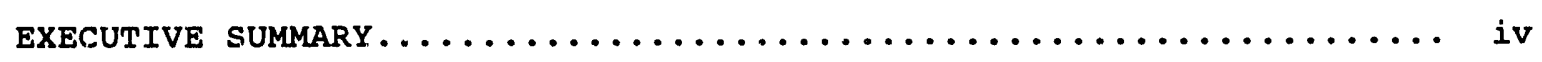

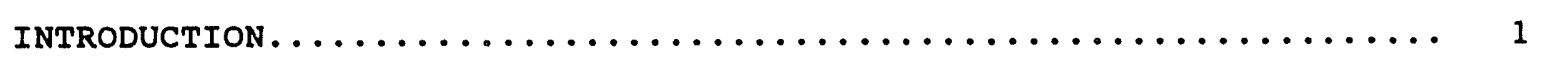

PREPARATION. ..................................

DESCRIPTION OF EQUIPMENT............................. 2

Pretreatment Tests............................... 2

Coprocessing Tests............................... 2

PROCEDURES ...................................... 5

Pretreatment Tests............................... 5

Coprocessing Tests................................. 5

RESULTS AND DISCUSSION.............................

Pretreatment Tests............................. 6

Coprocessing Tests.............................. 7

Concrusions $\ldots \ldots \ldots \ldots \ldots \ldots \ldots \ldots \ldots \ldots \ldots \ldots \ldots \ldots \ldots \ldots \ldots \ldots \ldots \ldots \ldots \ldots$

RECOMMENDATIONS................................... 15

ACKNOWLEDGMENT .................................. 16

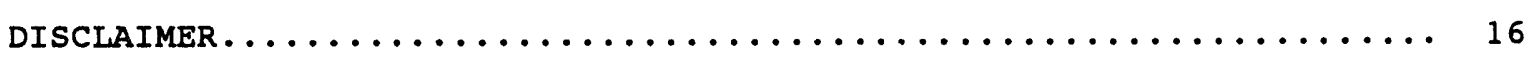

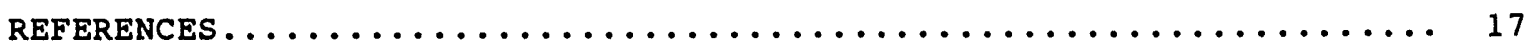

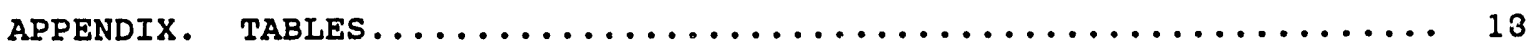




\section{LIST OF FIGURES}

\section{Figure}

Page

1. Process Flow Diagram for 1 -inch IFB system................

2. Process Flow Diagram for 2 -inch SPR system................ 4

3. Heavy oil Conversion to solids......................... 8

4. Oil-to-Char product Ratios...........................

5. Relationship Between Char Heating Values and Proximate volatiles for Herrin Coal.................... 11

6. Relationship Between Char Heating Values and Proximate Volatiles for Pittsburgh No. 8 Coal............... 12

7. Relationship Between Fischer Assay Volatiles and Proximate Volatiles for Herrin and Pittsburgh No. 8 Tests...... 13 


\section{EXECUTIVE SUMMARY}

This document describes research performed in accordance with task 3.3.1 in the 1989-1990 annual research plan under cooperative agreement number DE-FC21-86MC11076. The objective of this study was to determine the potential for enhancing liquid yields by integrating coal pretreatment and coprocessing technologies. The process tested involved pretreatment of coal to a very low moisture content and partial decarboxylation in an inclined fluidized-bed reactor by contact with hot $\mathrm{CO}_{2}$ or a $\mathrm{CO}_{2}$ and superheated steam mixture. The pretreated coal was then coprocessed with a heavy, coal-derived oil in a 2 -inch screw pyrolysis reactor to produce dried coal with a higher calorific value and an upgraded oil.

Six pretreatment tests and seven coprocessing tests were conducted independently with two separate systems being utilized: one system for the pretreatment tests and the other system for the coprocessing tests. The test program included evaluating alternative pretreatment gases, temperatures, and residence times in combination with different coprocessing temperatures and residence times. Pretreatment and coprocessing studies were performed on Herrin seam (Illinois No. 6) and Pittsburgh No. 8 coals. Pretreatment temperatures ranged from 253 to $420^{\circ} \mathrm{F}\left(123-216^{\circ} \mathrm{C}\right)\left(Z \circ{ }^{\circ} 4\right)$ at residence times of 1.7 and 2.3 minutes. The coals were fed to the pretreatment reactor at 20 to $31 \mathrm{lb} / \mathrm{hr}$. Coprocessing temperatures ranged from 501 to $698^{\circ} \mathrm{F}\left(261-370^{\circ} \mathrm{C}\right.$ ) (zone 4) and residence times were 13 and 21 minutes. The coal feed rate into the coprocessing reactor ranged from 4.1 to $8.1 \mathrm{lb} / \mathrm{hr}$. The oil feed rate ranged from 1.5 to $5.1 \mathrm{lb} / \mathrm{hr}$. Results of the integrated pretreatment and coprocessing operations were evaluated and compared with the coprocessing of raw coal.

The results of the experiments indicate that a solid product is formed with a higher calorific content than the starting coal and that an upgraded oil is generated. For the Herrin coal the highest solid product heating value achieved was $14,714 \mathrm{Btu} / \mathrm{lb}$ compared with 11,771 Btu/lb for the raw coal. The Pittsburgh No. 8 solid product reached a heating value of $14,436 \mathrm{Btu} / \mathrm{lb}$ compared with $13,343 \mathrm{Btu} / \mathrm{lb}$ for the raw coal. However, the combination of pretreatment and coprocessing caused an increase in the fixed carbon content of the solid product that would have an adverse effect on any subsequent processing. Pretreatment followed by coprocessing increased the fixed carbon in the solid product by as much as 51 wt 8 compared with the raw Herrin coal. For the Pittsburgh No. 8 coal the increase was by as much as 29 wt 8 . The liquid product is upgraded but the efficiency of that upgrade is in some cases low. As much as half of the desirable (pentane soluble) portion of the heavy oil is incorporated into the solid product. This results in a higher volatile content and a higher heating value for the solid product. 


\section{INTRODUCTION}

Laboratory studies suggest that coke formation during hydropyrolysis can be prevented by a prior treatment that involves immersing the coal in an inert liquid at temperatures between approximately 662 and $752^{\circ} \mathrm{F}$ $\left(350\right.$ and $400^{\circ} \mathrm{C}$ ) (Berkowitz and speight 1973). Such treatment removes moisture in the coal and raises its calorific value by as much as 10128. After the coal is coprocessed, it is more stable than the dried coal before the coprocessing step.

It is speculated that the presence of a suitable liquid within the pore system of the coal stops the collapse of pores that occurs at the onset of coking. The liquid allows hydrogen access to the pores by dissolution of the hydrogen in the liquid. The presence of the liquid, especially a hydrogen-donor liquid, will also enhance hydrogen transfer within the pore systems, thereby reducing potential coke-forming reactions.

Finally, the heavy oil that is coprocessed with the coal will be upgraded compared with the original material. Previous testing suggests that the primary mechanism for this upgrading step is distillation, which reduces the viscosity and the gravity of the product oil.

The objective of this task was to conduct an initial evaluation of the potential for enhancing liquid yields by integrating coal pretreatment and coprocessing technologies. The first step involved pretreatment of two eastern coals: one of high moisture content and one of low moisture. Alternative pretreatment gases, temperature, and residence times were evaluated.

After the two eastern coals were pretreated, the coal was coprocessed with a heavy coal tar in the screw pyrolysis reactor (SPR). Coprocessing was conducted with different temperatures and residence times to determine the best coprocessing conditions. Results of the integrated pretreatment and coprocessing operations were evaluated and compared with the coprocessing of raw coal.

The thermal pretreatment stage of the experiments was performed in an inclined fluidized-bed (IFB) reactor. The IFB reactor is ideally suited for thermal pretreatment of fine coal particles (Boysen et al. 1990). This thermal pretreatment can open the coal pore structure by removing moisture and decarboxylating the coal. The gas used in the pretreatment can enhance the coal reactivity by modifying reactive sites.

Upon exiting the IFB, the pretreated coal was immersed in a heavy oil. In a fully integrated operation, this step would be accomplished by connecting the IFB and SPR units for steady-state operation. TO better understand the operation of the two systems prior to hooking the systems together, each system was operated independently in a semibatch mode. 


\section{PREPARATION}

To start the coal pretreatment tests, two eastern coals were obtained (Table 1). The first was a Herrin seam (Illinois No. 6) low moisture bituminous coal from the Peabody Coal Company River King Mine, pit 3, near New Athens, Illinois. The Herrin coal had been stored onsite for 2 years in air-tight drums. Analysis of this coal showed that no parameters that would indicate weathering had changed significantly during storage.

The second coal was provided by Consolidation coal company and was a high moisture, Pittsburgh No. 8, filter cake coal. Unlike Powder River Basin coal which is naturally high in moisture; the pittsburgh filter cake coal had a high water content because of previous processing. This material was a wet, pasty material that could not be processed as received and had to be air dried prior to pretreatment in the IFB (Table 1).

Prior to processing, both the Herrin and the Pittsburgh No. 8 coal were crushed and screened to a minus 16-mesh particle size. Table 2 contains the screen analyses for the two coals.

The heavy oil used in the coprocessing tests was produced from mild gasification experiments conducted on western, Powder River Basin coal in a fluidized-bed pyrolyzer (Merriam and Jha 1991). The oil was collected from the electrostatic precipitato: and water-cooled condenser at the outlet of the pyrolyzer. The properties of this oil are shown in Table 3 .

\section{DESCRIPTION OF EQUIPMENT}

\section{Pretreatment Tests}

The 1-inch inclined-fluidized-bed reactor (IFB) is constructed of 304 stainless steel and has solids sample collection ports and thermocouples installed in the bed. The pretreatment system consists of a gas meter and heater, the reactor, a variable-speed screw feeder, a cyclone, a dust filter, condensers, and a gas-water separator (Figure 1). Dried coal exiting the IFB is immediately immersed in a preheated, tared barrel of heavy oil.

\section{Coprocessing Tests}

A schematic of the 2-inch SPR system is shown in Figure 2 . The dried coal, heavy oil slurry produced from the pretreatment step is fed into the inclined screw reactor by the screw feeder. If needed to facilitate feeding, additional oil is injected concurrently with the coal. As the slurry mixture moves through the first two-thirds of the inclined screw; the coal and oil are heated, vapor products are swept from the system, and the upgraded oil is condensed in the knockouts. 


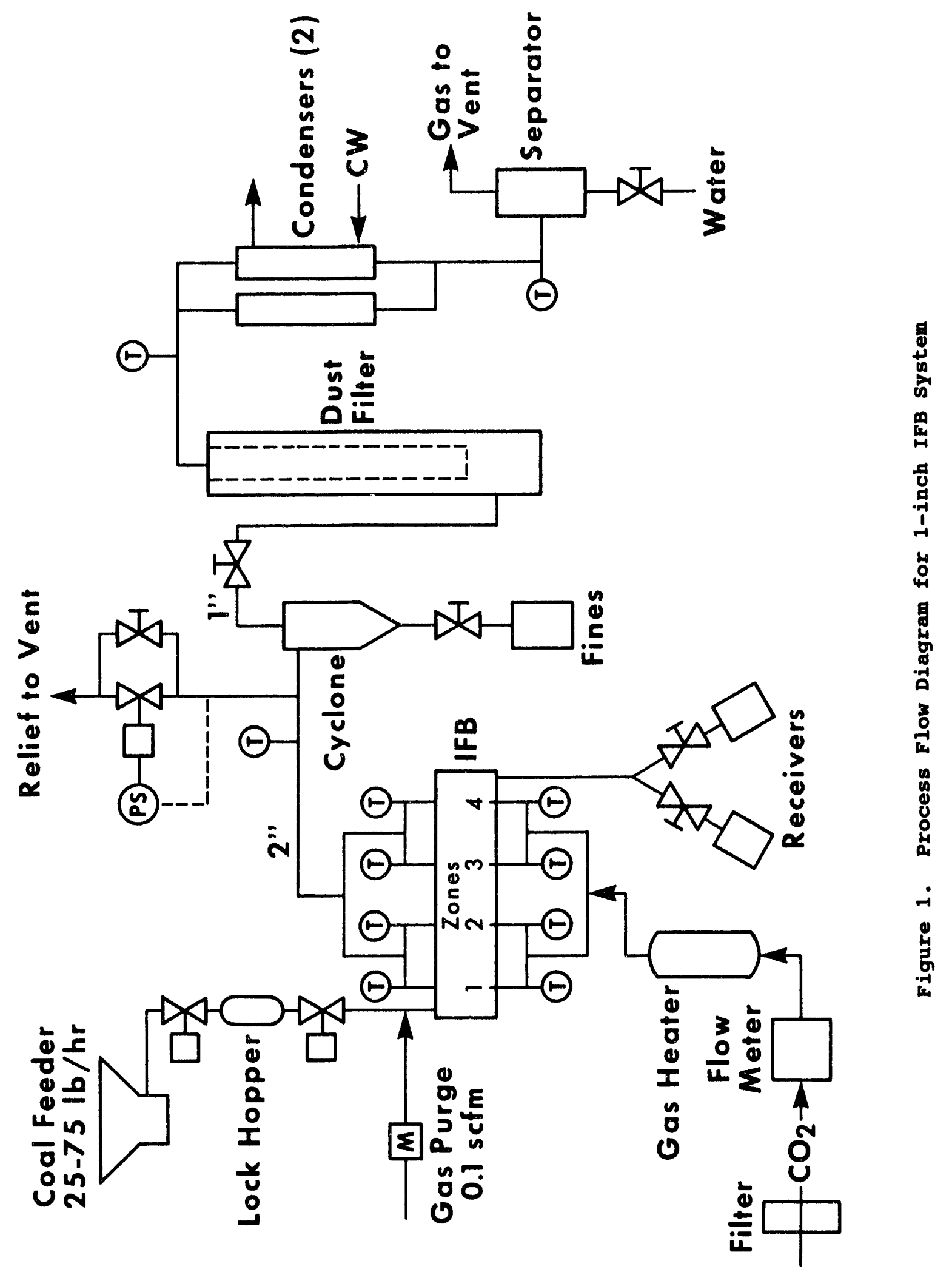




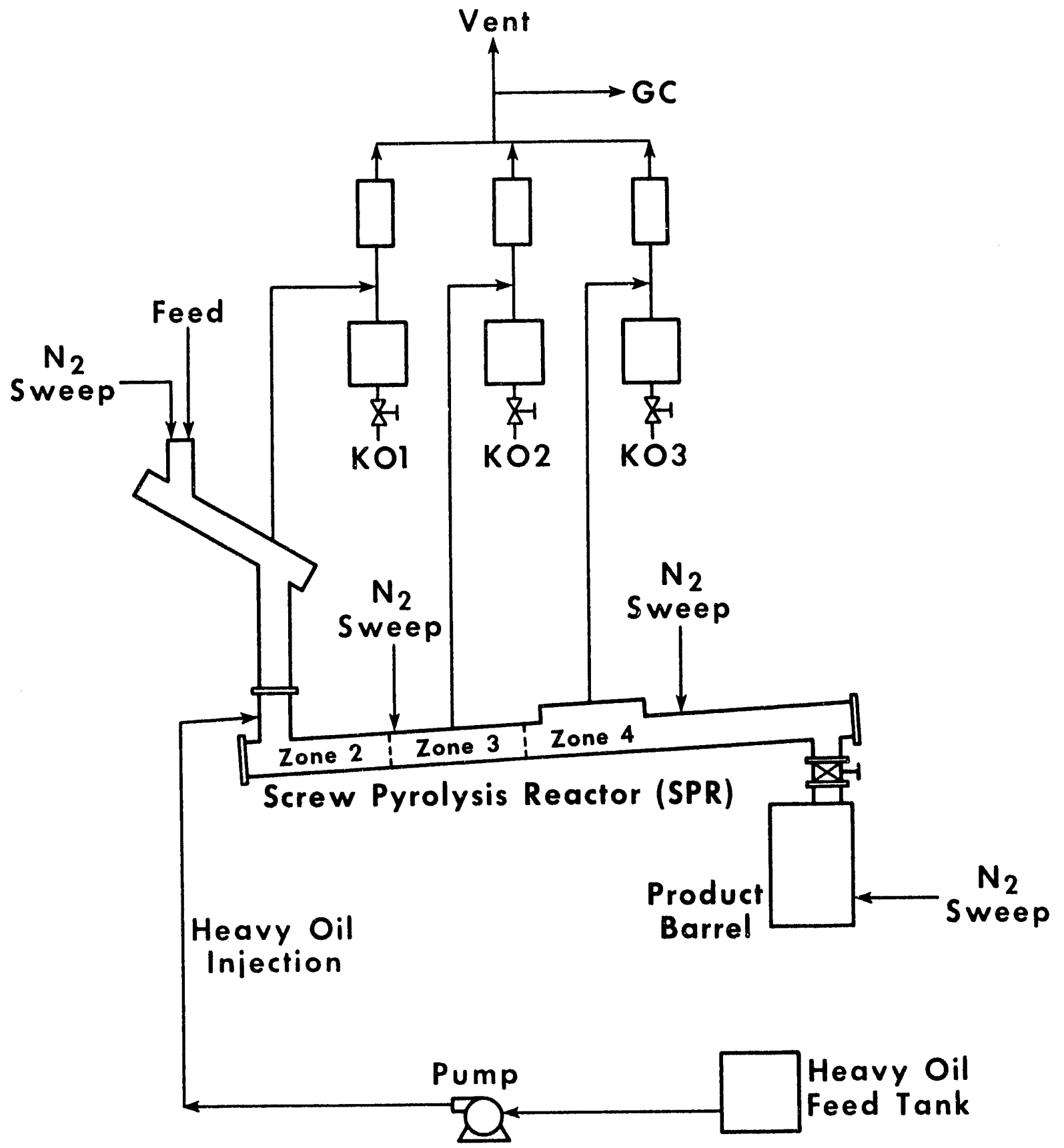

Figure 2. Process Flow Diagram for 2-inch SPR System 
The remaining coal and heavy oil are exposed to higher temperatures in the last one-third of the screw conveyor. Here additional oil is recovered, and the coal is stabilized. Depending on the temperature, residence time, and heavy oil injection rate, a dried or semidried product exits the SPR and is collected for the liquefaction tests to be conducted as a separate task.

\section{PROCEDURES}

\section{Pretreatment Tests}

once the coals were crushed to size, several short tests were performed to calibrate the coal feeder and to obtain the proper balance of gas flow rate to minimize the amount of entrained fines leaving the pretreatment system.

The pretreatment test conditions are shown in Table 4 . Pretreatment coal feed rates ranged between 19.7 and $30.9 \mathrm{lb} / \mathrm{hr}$ and pretreatment residence times were 1.7 and 2.3 minutes. Pretreatment of the coal was conducted in the $253-266^{\circ} \mathrm{F}\left(123-130^{\circ} \mathrm{C}\right)$ range for the low-temperature tests and in the $400-420^{\circ} \mathrm{F}\left(204-216^{\circ} \mathrm{C}\right)$ range for the high-temperature tests. These pretreatment temperatures are lower than initially proposed to minimize swelling of the eastern coals.

Carbon dioxide was used as the fluidizing gas in pretreatment tests 1 and 2 with Herrin coal and in tests 5 and 6 with the Pittsburgh No. 8 coal. For pretreatment tests 3 and 4 , a mixture of $\mathrm{CO}_{2}$ and superheated steam was used as the fluidizing gas. The gas mixture contained 64 vol 8 carbon dioxide and 36 vol o superheated steam. The raw coal feed rate was reduced for tests 3 and 4 because the steam softened the coal causing minor plugging of the lock hoppers.

The dried coal was immersed in coal derived oil upon exiting the 1inch IFB. For each test, 125 lb of the coal-derived heavy oil were placed in recovery barrels. These slurries were used as the feed material for the coprocessing runs.

\section{Coprocessing Tests}

The dried coal, heavy oil slurry from each of the pretreatment stages was used for one series of three or four experiments in the screw pyrolysis reactor. Test conditions for the coprocessing of Herrin coal pretreated in a carbon dioxide atmosphere are listed in Table 5 . The test number (i.e. Cop-1-2) refers to a coprocessing experiment (Cop), a pretreatment condition $(-1)$, and the test number in the coprocessing series for that pretreatment condition (-2). The temperatures in the different SPR regions are listed. Refer to Figure 2 for the locations of the temperature zones. Test durations and material residence times are also listed. The coal concentration is the weight percent of coal in the total feed. This includes the coal-heavy oil slurry, the heavy oil feed, and any additional oil added to facilitate material feeding. 
The feed rate is the rate at which the coal-heavy oil glurry and additional facilitating oil are added. The oil rate is the rate at which heavy oil is pumped into the system. The nitrogen flow rate is sweep rate of gas through the system.

Series 001 was discontinued early due to severe plugging of the screw reactor system caused by high temperatures. For this reason run 4 was abandoned. To force a longer oil-to-coal contact time and to better process the solids, the temperatures were lowered for series 002 .

Test conditions for the coprocessing of Herrin coal pretreated in a $\mathrm{CO}_{2}$ steam atmosphere are listed in Table 6. A similar listing for coprocessing Pittsburgh No. 8 coal pretreated with $\mathrm{CO}_{2}$ is shown in Table 7. Conditions for coprocessing an unpretreated Herrin coal are listed in Table 8. Series 007 was terminated early because of plugging and run 27 was abandoned.

Material residence times and coprocessing temperatures were the key experiment variables in each coprocessing series. In addition, the amount and kind of oil added to the feed hopper to ensure proper feeding depended on how smoothly the feeder was operating. In some cases no additional oil was necessary, however, for many tests the addition of heavy oil or knock-out oil was essential. In series 007 knock-out oil from previous tests was mixed with raw, unpretreated coal to obtain a slurry for feeding. In each of the other tests where knock-out oil was added, the oil was produced in the same test.

\section{RESULTS AND DISCUSSION}

\section{Pretreatment Tests}

Material balances for the pretreatment tests are shown in Table 9. In general, higher temperatures and longer residence times resulted in higher fines production. Pretreatment temperatures and residences times in tests 1 and 3 were not severe enough to remove all the moisture from the coal (Table 10). In other tests virtually all the moisture was removed. The addition of superheated steam to the IFB increased the fines production but had little other readily apparent effect.

The effects of pretreatment on the Herrin coal are shown by the proximate, ultimate and Fischer assay analyses in Table 10. The proximate results indicate again that conditions were not sufficiently severe in tests 1 and 3 to remove all the moisture. Overall the effects of pretreatment appear minor. There is a slight increase in the average volatile matter content, 38.98 compared to 37.98 for the raw coal, and a slight decrease in the average fixed carbon content, 49.88 compared to 51.28 for the raw coal. The average ash content is higher in the pretreated coal than in the raw coal, 11.28 compared to 10.98 in the raw coal. The ultimate analyses indicate a slightly higher carbon content and a lower oxygen content in the pretreated samples. Pretreatment also improves the heating value of the coals by an average of about $4 \%$. Fischer assay shows lower water production and higher gas production from the pretreated coals. 
Except for coal-drying effectiveness, the effects of pretreatment temperature and atmosphere are small. The fixed carbon content of the coal increases with temperature increases, and decreases when steam is added to the system. Higher temperatures cause a slight increase in product heating value.

The effects of pretreatment on the Pittsburgh No. 8 coal are shown by the analyses in Table 11. The proximate analyses indicate that virtually all the moisture was removed from the coal by pretreatment. As with the Herrin coal, the volatile matter increases slightly when the coal is pretreated. Fixed carbon decreases and ash content increases when the coal is pretreated. The ultimate analyses indicate higher carbon content and lower oxygen content in the pretreated samples. The heating value in test 5 is higher than that of the raw coal and the heating value in test 6 is lower, but the differences are small (<1.58). Fischer assay shows little difference between the pretreated and raw coal samples.

\section{Coprocessing Tests}

\section{Material Balances}

Material balances for the coprocessing tests are summarized in Table 12. Although each series consists of three or four tests and product samples were collected for detailed analyses at the end of each test, complete feed and recovery values are only available for the series. The feed and recovery amounts for series 001 include only tests 1, 2, and a preliminary warmup period. A major plugging problem resulted in test 4 of series 001 being aborted. The plugging was so severe that the knock-out pots appeared to be filling with raw heavy oil that could not pass through the plugged system. This resulted in high apparent liquid yield and perturbed char values because little heavy oil contacted the coal. Test 3 of series 001 is included in the material balance for series 002 .

The weight of the char formed during coprocessing is greater than the weight of coal fed. This increase in solid weight must result from conversion of heavy oil to solid. Since a small amount of the coal could have been converted to gaseous and liquid products, the difference in weight between the char and the coal is the minimum weight of heavy oil converted to solid. This value, as a percent of the heavy oil fed and as a percent of the total char formed, is shown plotted as a function of maximum coprocessing temperature in Figure 3 . For the Illinois pretreated coal, with the exception of series 001 , the amount of heavy oil going to char and the amount of char coming from the heavy oil are reduced as the coprocessing temperature increases. The percent of heavy oil forming char goes from 828 in series 004 to 638 in series 002. Similarly, the percent of the product char that is derived from the heavy oil drops from 668 to 578 over the same series. 


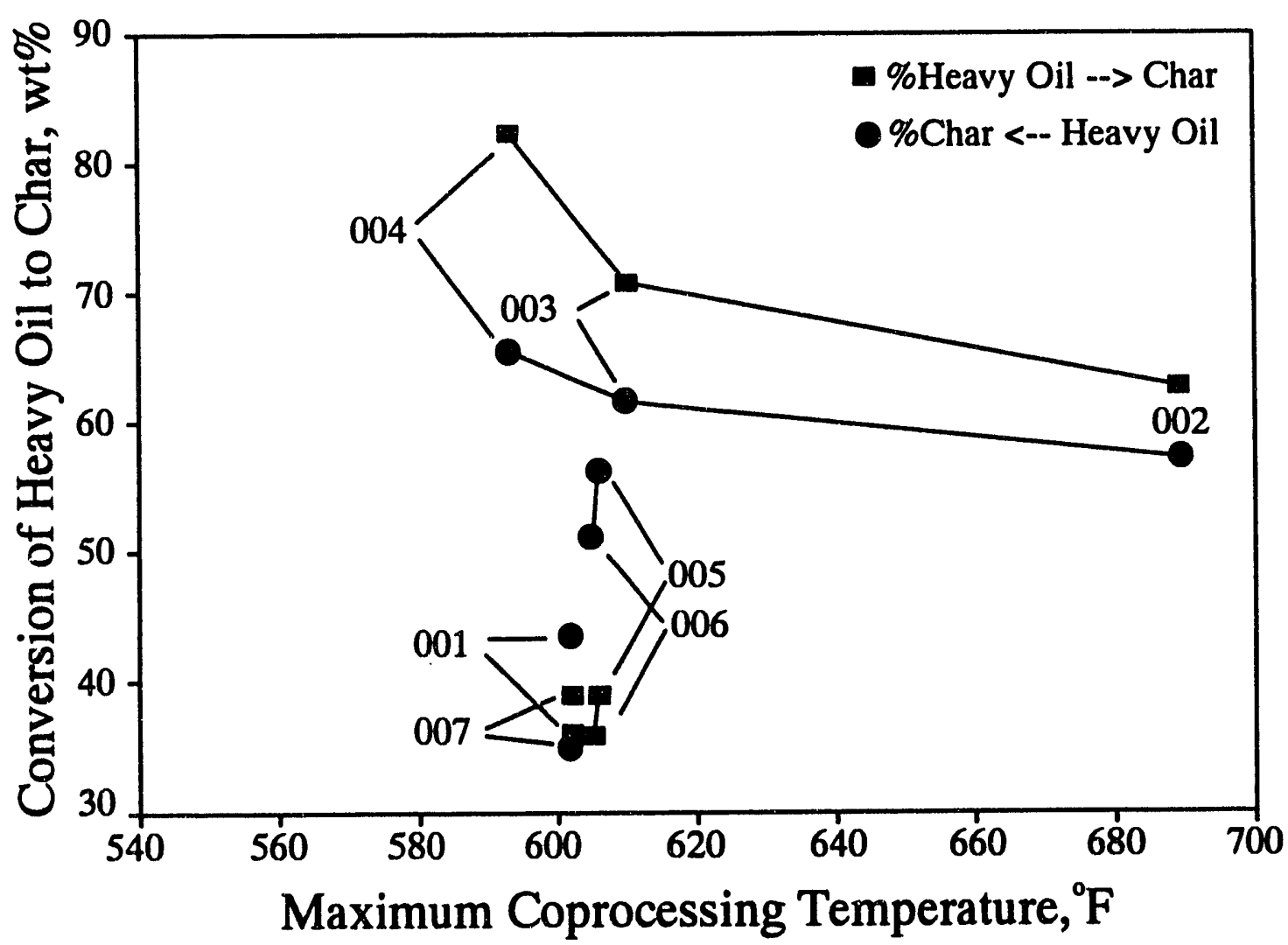

Figure 3. Heavy oil Conversion to solids

series 007 , the tests with unpretreated Herrin coal, show dramatically different behavior, a factor of two different than tests with the pretreated coals. Only 358 of the product char is oil derived and only 398 of the heavy oil forms char. clearly, the pretreated coal binds the heavy oil more strongly than the unpretreated coal.

The coprocessing series with the Pittsburgh No. 8 coal (series 005 and 006 ) were performed with a higher starting oil-to-coal ratio $(-3: 1)$. However, less heavy oil formed char, 36-398, and less product char was derived from heavy oil, 51-56\%, than in similar experiments with pretreated Herrin coal. The percent of heavy oil forming char in the Pittsburgh No. 8 coal tests is as low as trat for the unpretreated Herrin coal coprocessing series.

The values from series 001 are obviously outliers in Figure 3 . Their deviation is even more clear when the oil-to-char product ratio is plotted as a function of maximum coprocessing temperature (Figure 4 ). As might be expected, the ratios from series 002,003 , and 004 follow a consistent pattern indicating more knockout oil production at higher coprocessing temperatures. Series 001 , however, produced far more oil than expected, consistent with heavy oil production from the knockout pots as discussed above. The unpretreated Herrin coal (series 007 ) and the pittsburgh No. 8 coal show high oil-to-char ratios resulting from less heavy oil conversion to char. 


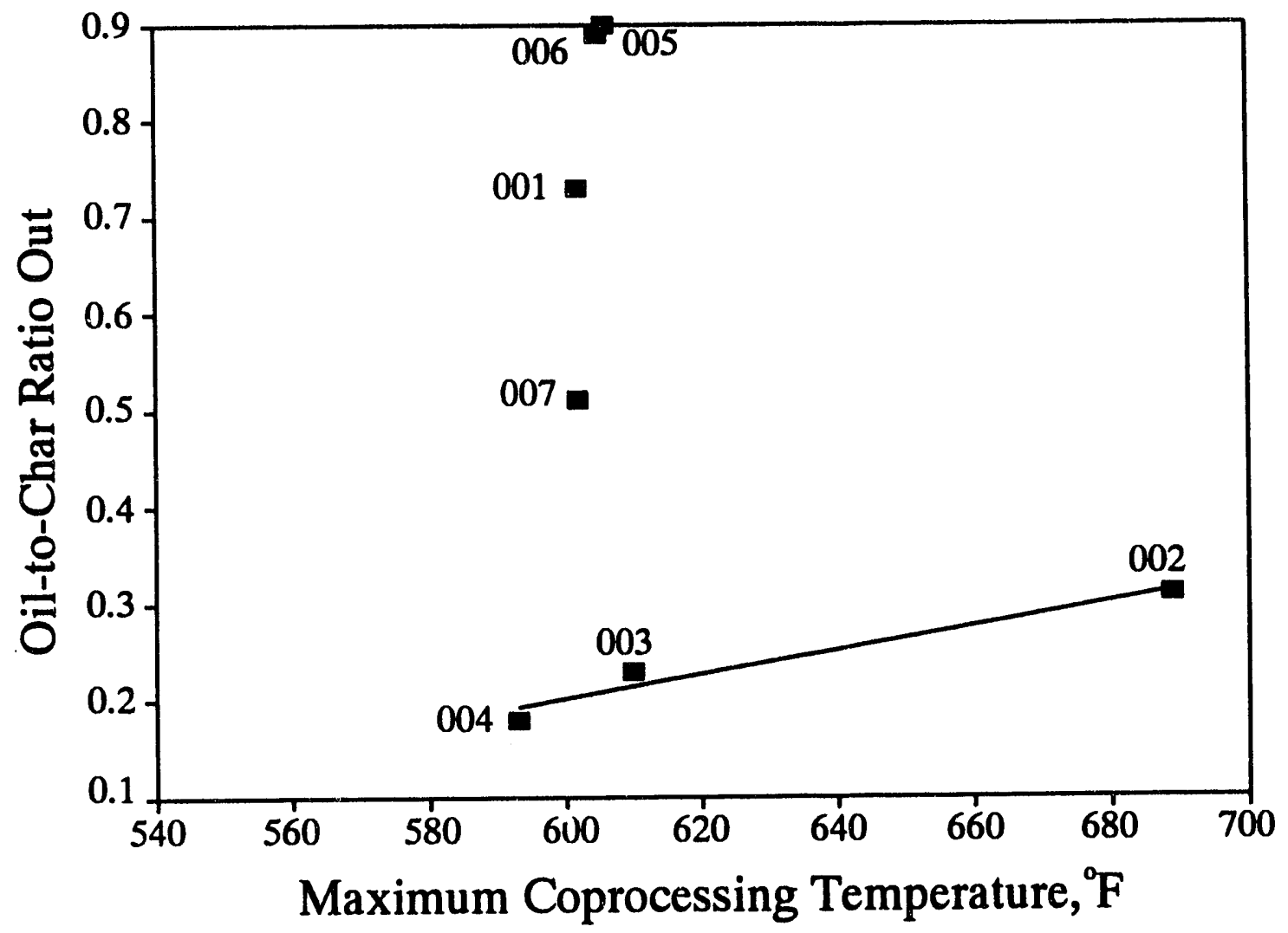

Figure 4. Oil-to-Char Product Ratio

\section{Char Analyses}

The results of solid product analyses are listed in Tables 13 and 14 for the tests with pretreated Herrin coal and in Table 15 for the Pittsburgh No. 8 coal. The analysis results on the unpretreated Herrin coal coprocessing tests are listed in Table 16. It was not always possible to complete the Fischer assay analyses on the spent coal material. In many cases the solid material swelled so much that the system plugged. on disassembly, the analyst discovered a solid, "foamed" material filling the reactor and outlet tubing. proximate analyses, with their much smaller sample size, were always possible.

The proximate analyses for the tests with pretreated Herrin coal vary little with operating conditions. The average moisture-free volatile value for series 002 through 004 is 62.38 with a standard deviation of 1.78. All the volatile matter measurements in series 001 and 007 are more than two standard deviations below the average. As mentioned earlier, series 001 is suspect because of severe plugging and the possible "production" of feed, heavy oil. series 007 is the coprocessing test set using unpretreated Herrin coal. The difference in proximate volatile matter between tests in this series and series 002 through 004 indicates a significant effect of pretreatment. 
The principle hypothesis leading to this research was that coke formation during hydropyrolysis could be prevented by an appropriate pretreatment regime. This research task does not involve the hydropyrolysis stage of the experiment (a separately reported task), but it is of interest to examine changes in coke formation during the pretreatment and coprocessing stages of this work. This can be accomplished by first assuming ash conservation through the two stages, the ash weight in the product char is equal to the ash weight in the feed coal. The next step is to divide the proximate fixed carbon percent by the proximate ash percent for the raw coal, pretreated coal, and the char (or spent coal). This generates a set of dimensionless parameters proportional to the amounts of fixed carbon in the raw coal, pretreated coal, and char. Ratios of these parameters provide a measure of the fixed carbon (or coke) change during each of the experiment stages. For example the fixed carbon/ash ratio in the char divided by the fixed carbon/ash ratio in the pretreated coal gives the factor by which fixed carbon changes during coprocessing. Similarly, the change in fixed carbon during pretreatment and the overall change in fixed carbon through both stages can be determined. Tables 17 through 20 show the results of these calculations for both coals and all pretreatment regimes.

Both coals show a slight decrease in fixed carbon during pretreatment, down to 938 of the raw coal values for $\mathrm{CO}_{2} /$ steampretreated Herrin and 958 for Pittsburgh No. 8 coals. Pretreatment of Herrin coal in $\mathrm{CO}_{2}$ at $400^{\circ} \mathrm{F}$ results in only a 18 decrease in fixed carbon. Coprocessing, in general, has an adverse effect on the fixed carbon content of the solid products. During coprocessing, the fixed carbon content of $\mathrm{CO}_{2}$-pretreated Herrin coal increases by up to 198 (series 002). However, when $\mathrm{CO}_{2} /$ steam pretreatment is used (series 003 and 004 ), the fixed carbon content of the product char is increased by up to 638 during coprocessing. The net increase (pretreatment and coprocessing) in fixed carbon is as high as 518 for $\mathrm{CO}_{2} /$ steam-pretreated Herrin coal. Only the unpretreated Herrin coal shows a consistent net reduction in fixed carbon during coprocessing. The data for the Pittsburgh No. 8 coal are more scattered but indicate an average total increase in fixed carbon of 98 for combined pretreatment and coprocessing.

The average char heating value over series 002 to 004 is 14,388 Btu/lb with a standard deviation of $139 \mathrm{Btu} / \mathrm{lb}$. Two out of three char heating values in series 001 and all heating values in series 007 are more than two standard deviations below this average (Tables 1, 13-16), but are still higher than the raw coal except for Cop-7-4. Pittsburgh No. 8 coal also had an increase except for cop-5-3 and cop-5-4. The similarities in the trends in heating values and proximate volatiles are shown in a plot of heating value as a function of proximate volatile matter content (Figure 5). All the outlying points in this plot are from series 001 and 007 with a point for raw Herrin coal shown for comparison. All other points are clustered in a small region, although the trend is chat increasing volatile matter results in increasing heating value. Points for tests $007-1$ and $007-2$ are extensions of that trend at lower values of volatile matter and heating value. The point for raw Herrin coal is not far from the trend line at a lower volatile content and lower heating value. 


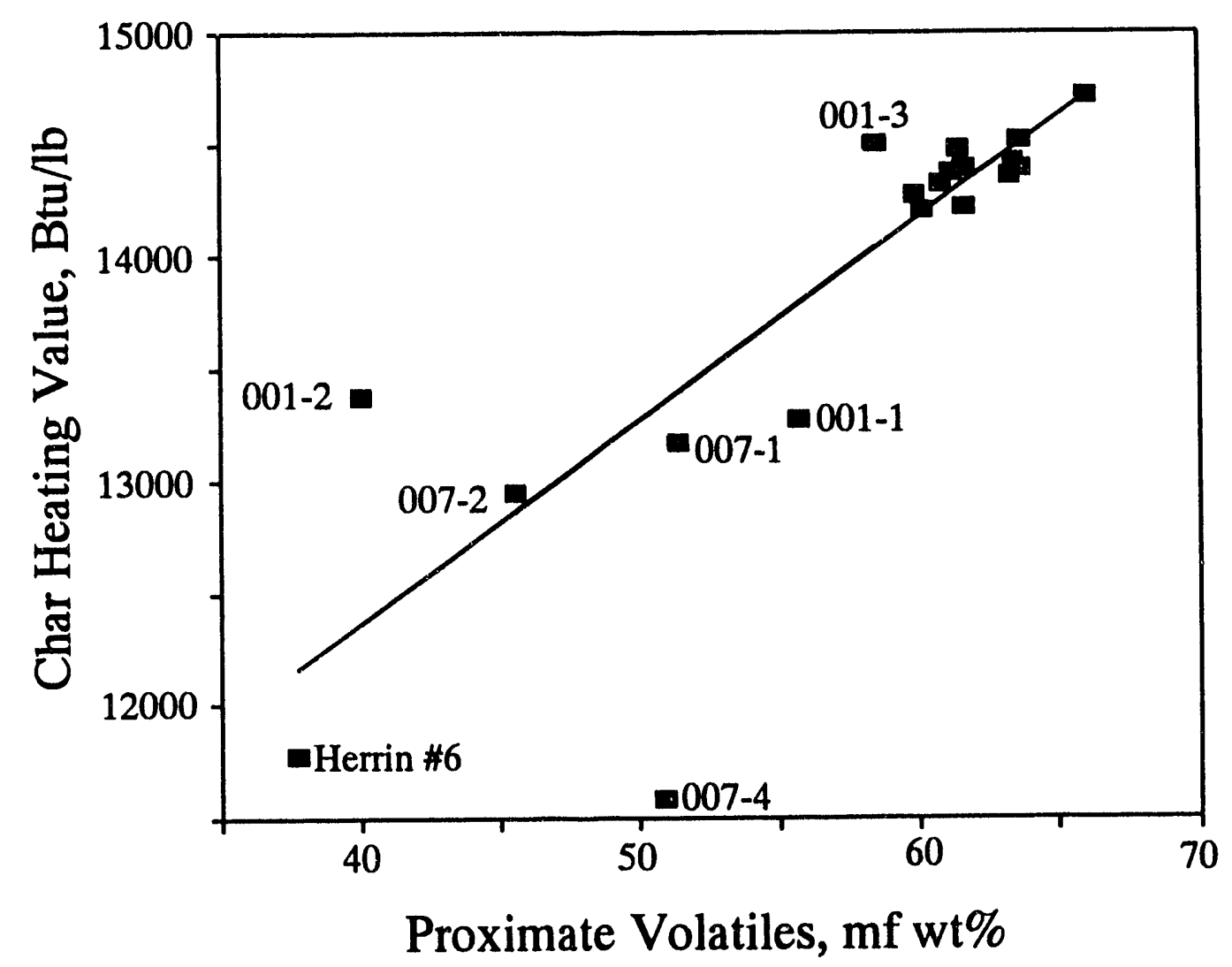

Figure 5. Relationship Between Char Beating Values and proximate Volatiles for Herrin Coal

Figure 5 shows that coprocessing generally increases both the heating value and the volatile content of the product char. However, pretreated coal shows a more dramatic and consistent increase than unpretreated coal.

The coprocessing series with Pittsburgh No. 8 pretreated coal produced a char with an average proximate volatile content of 57.18 with a standard deviation of 6.68 . The average heating value for tests in these series is $13,840 \mathrm{Btu} / 1 \mathrm{~b}$ with a standard deviation of $515 \mathrm{Btu} / 1 \mathrm{~b}$. The volatile content of the raw Pittsburgh No. 8 conl on a moisture-free basis is 33.48 and the heating value is $13,343 \mathrm{Btu} / \mathrm{lb}$. The coprocessed, pretreated Pittsburgh No. 8 coal produces a char with substantially more scatter in its volatile contents and heating values. Although the average volatile content is increased 718 over the raw coal, the heating value of the raw coal is within one standard deviation of the average for all the coprocessing tests. A plot of heating value as a function of volatile content (Figure 6 ) shows little trend to the data. 


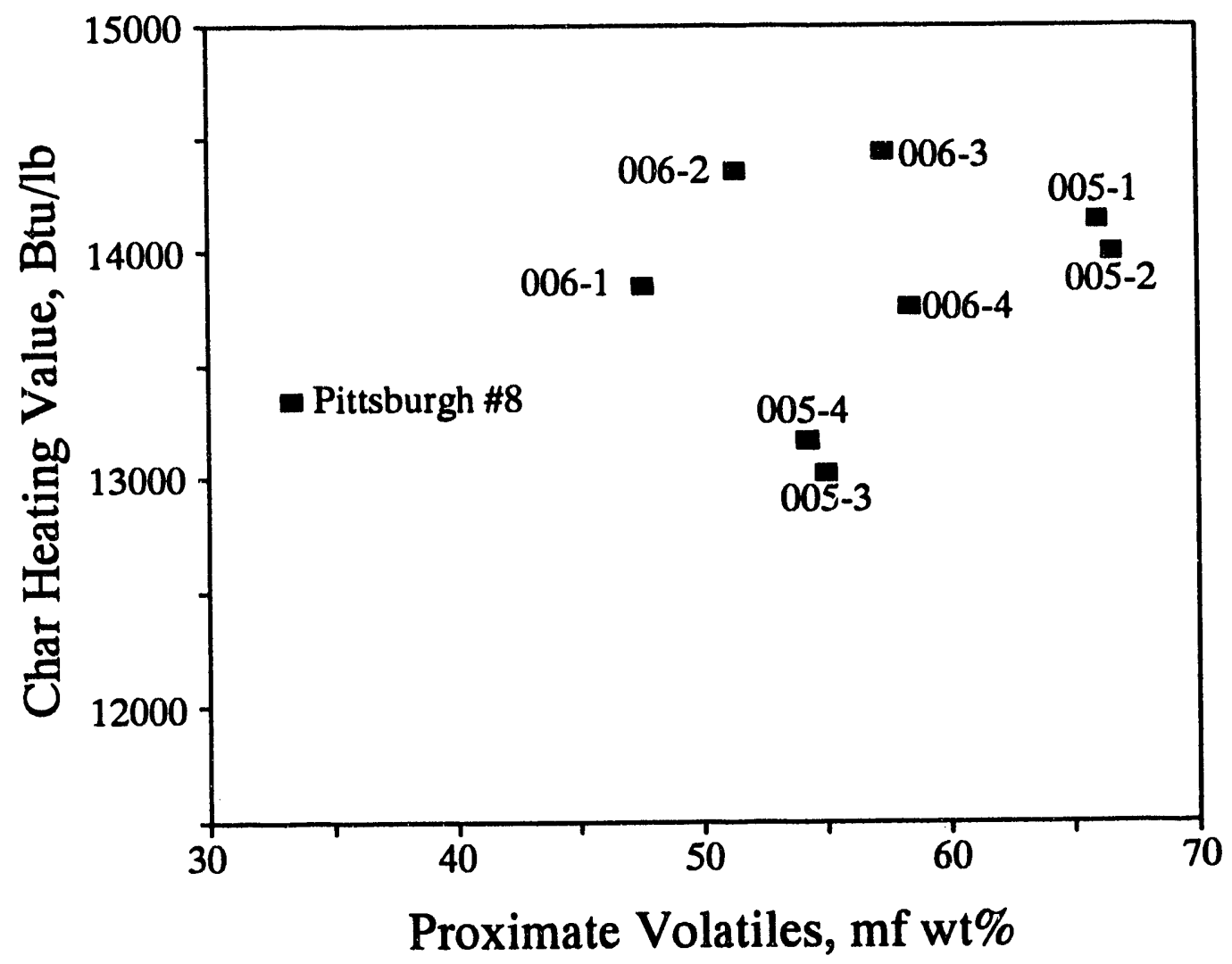

Figure 6. Relationship Between Char Heating Values and Proximate Volatiles for Pittsburgh No. 8 Coal

Fischer assay results mimic those of the proximate analyses. For example, the Fischer assay volatiles (gas + oil + water) can be plotted against the proximate volatiles to obtain a linear relationship (Figure 7). This figure contains all the Fischer assay volatile values including both Herrin and Pittsburgh No. 8 raw coals and all available values from the coprocessing products. The slope of the least-squares, best-fit line is 1.01 indicating a near $1: 1$ correlation between the Fischer assay volatiles and the proximate volatiles. The effects of pretreatment are seen in the values for the Herrin raw coal, the coprocessed, unpretreated Herrin samples (series 007), and the coprocessed, pretreated Herrin samples (series 002, 003, and 004). The results for tests in coprocessing series 001 are again anomalous, but do not fall far from the least-squares line. 


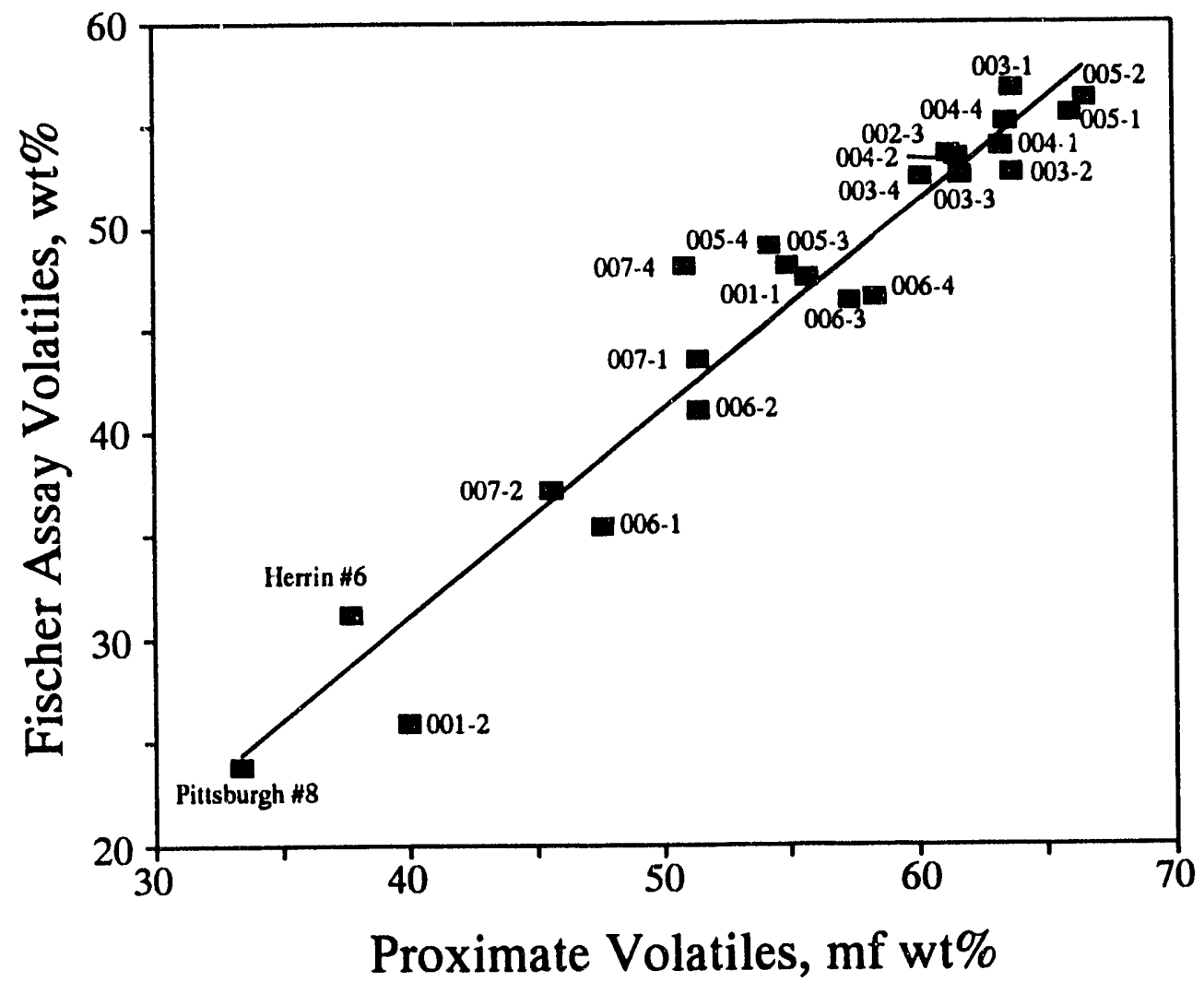

Figure 7. Relationship Between Fischer Assay Volatiles and Proximate Volatiles for Herrin and Pittsburgh No. 8 Tests

\section{Liquid Analyses}

Many of the liquid samples from the coprocessing tests separated into two oil phases. Because of this, accurate analyses of the whole samples would have been difficult. Instead, the samples were first mixed thoroughly using a shaker and then separated into solubility fractions. The solvents used were pentane, toluene, and tetrahydrofuran (THF), solvents commonly used to evaluate coal liquids. The solubility fractions from the product oils from selected coprocessing tests were submitted for determination of elemental composition. The specific gravity and distillate range of the pentane-soluble fractions were also determined.

The solvent fractions and the results of analyses on those fractions are listed in Tables 21 and 22. Compared to the original heavy oil (see rable 3 ) the pentane-solubles component of the product oils is consistently a much higher percentage of the oil, averaging 84.8 wt 8 compared to 61.8 wt 8 . The toluene-plus-THF fraction goes from 38.2 wt 8 of the original oil to an average of 15.2 wt 8 of the upgraded oil. The distillation profiles of the pentane-soluble portions of the product oils are shifted to lower temperatures and there is less material distilling above $1000^{\circ} \mathrm{F}$ than in the heavy oil. 
The recovery of pentane-soluble material can be estimated by averaging the available product oil pentane-solubles percents for each series and assuming that average is accurate. This number (as a fraction) times the weight of knock-out oil recovered yields the weight of pentane-soluble material recovered. The calculation of the weight of pentane-soluble material fed is more straight forward, being 61.8 wt 8 of the heavy oil feed. Series 007 poses a little more difficulty because knock-out oil from previous tests was used to slurry the raw coal. By assuming the feed knock-out oil has the same solubility properties as the product oil, the recovery of pentane soluble material can still be estimated. The weights and conversions resulting from these calculations are shown in Table 21 . These recovery percents indicate that although the product oil is upgraded, there may be significant losses of pentane-soluble product. These losses are as much as 53 wt 8 for the Herrin tests and 14 wt 8 for the Pittsburgh No. 8 tests. The relatively high recovery of pentane-soluble material in series 007 is probably because of the high knock-out oil content of the feed oil.

\section{Gas Analyses}

The relatively low severity coprocessing conditions generated very little gas. As shown in the material balance (Table 12), the total gas production for any series of tests never exceeded 2 wt 8 . The individual gas analyses and gas heating values are listed in Tables 2326. Carbon dioxide is the predominant gas species in the product gas, followed by hydrogen sulfide, methane, and carbon monoxide. Occasional high values of the $C_{5}$ and $c_{6}$ hydrocarbons indicate sporadic cooling condenser behavior. One effect of pretreatment is the difference in the product gas hydrogen sulfide content between tests with pretreated coal and tests with raw coal as feed. The average hydrogen sulfide content of the product gas stream in series 007 is 9.6 vol 8 compared to 16.3 vol \& for all the other coprocessing tests.

\section{CONCLUSIONS}

Several of the perceptions held at the beginning of this study must be discarded or modified. Drying, regardless of the conditions, reduces fixed carbon (or coke) in the Herrin and Pittsburgh No. 8 coals only a minor amount, typically 1-7 wt 8 . However, the drying conditions do have an effect on the amount of fixed carbon formed during coprocessing. Coprocessing of a Herrin coal pretreated in a $\mathrm{CO}_{2}$ atmosphere increases fixed carbon by as much as 18 wt of over the raw coal. Coprocessing the same coal pretreated in a $\mathrm{CO}_{2} /$ steam atmosphere results in an increase in fixed carbon content by as much as 51 wt 8 . This obviously has a negative effect on any subsequent hydro-processing, fixed carbon being more difficult to convert. Unpretreated coal showed a net reduction of fixed carbon during coprocessing.

The heating values of the solid products of coprocessing show an increase over raw coal. This is presumably because of the incorporation of heavy oil components into the coal structure. This may also be the reason for the "foaming" seen during Fischer assays. Excessive swelling such as this may limit processing options. 
The reactivity of the coals is increased by pretreatment. This is seen both in the increased fixed carbon production and in the binding of heavy oil to the solid. A substantial amount of the original heavy oil ends up in the solid product. This amount reaches over 808 in series 004. The resulting solid product is typically over 50 wt 8 heavy oilderived for the pretreated Herrin coal tests. When the coal is not thermally pretreated less oil ends up in the solid product.

The liquid product of the coprocessing regime is definitely upgraded. However, much of the desirable liquid material (pentane soluble) is lost in the process. The solid product holds tightly to the heavy oil components including much of the pentane soluble material.

\section{RECOMMENDATIONS}

Pretreatment alone and coprocessing alone lower the fixed carbon content of the dried coal or char product. What was not investigated, but is of interest, is the effect of pretreatment followed by immersion on liquefaction yields. The coal is obviously activated by pretreatment, but fixed carbon formation is delayed until the slurry is coprocessed. This delay provides a window wherein the activated coal may be hydroprocessed, possibly enhancing liquefaction oil yields while inhibiting coke formation. Small-scale experiments addressing this idea are easily designed and should be performed.

The strong binding of the heavy oil to the pretreated coal may be of economical importance for other coals, specifically western coals, where drying (pretreatment) followed by coal stabilization could extend the profitable shipping range for these coals. optimal pretreatment conditions and stabilizing-oil properties should be determined for western coals, followed by an economic assessment of the resulting process. 


\section{ACKNOWLEDGEMENT}

The authors express appreciation to the United States Department of Energy for funding of this work under Cooperative Agreement Number DEFC21-86MC11076.

\section{DISCLAIMER}

Mention of specific brand names or models of equipment is for information only and does not imply endorsement of any particular brand. 


\section{REFERENCES}

Berkowitz, N., and J.G. Speight, 1973, Prevention of "spontaneous Heating" by Low-Temperature Immersion Carbonization of Coal. The Canadian Mining and Metallurgical Bulletin, August 1973.

Boysen, J.E., C.Y. Cha, F.A. Barbour, T.F. Turner, T.W. Kang, M.H. Berggren, R.F. Hogsett, and M.C. Jha, 1990, Development of an Advansed Process for Drying Fine Coal in an Inclined Fluidized Bed, Final Report. Laramie, WY, WRI Report to DOE, DOE/PC/88886-T5.

Merriam, N.W., and M.C. Jha, 1991, Final Report - Development of an Advanced, Continuous Mild-Gasification Process for the Production of Co-Products. Laramie, WY, WRI Report to DOE, WRI-91-R068. 
APPENDIX.

TABLES 
1. Analyses of Raw Coals............................ 21

2. Screen Analyses for Raw Feed Coal, wt 8 Retained........... 22

3. Properties of Coal-Derived Heavy 0il.................... 23

4. Pretreatment Test Conditions......................... 24

5. Coprocessing Conditions for Herrin Coal, $\mathrm{CO}_{2}$ Pretreatment..... 25

6. Coprocessing Conditions for Herrin Coal, $\mathrm{CO}_{2} /$ steam........... 26

7. Coprocessing Conditions for Pittsburgh No. 8 Coal, $\mathrm{CO}_{2} \ldots \ldots \ldots 27$

8. Coprocessing Conditions for Unpretreated Herrin Coal, No Pretreatment................................ 28

9. Material Balances for Pretreatment Tests................. 28

10. Product Analyses for Pretreatment Tests on Herrin Coal....... 29

11. Product Analyses for Pretreatment Tests on. Pittsburgh No. 8 Coal 30

12. Coprocessing Material Balances....................... 31

13. Solid Product Analyses for Coprocessed Herrin Coal, $\mathrm{CO}_{2} \ldots \ldots \ldots$

14. Solid Product Analyses for Coprocessed Herrin Coal,

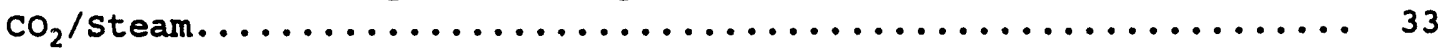

15. Solid Product Analyses for Coprocessed Pittsburgh No. 8 Coal,

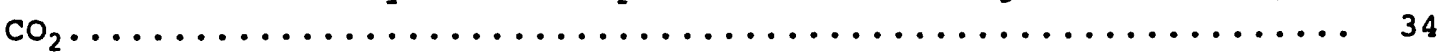

16. Solid Product Analyses for Coprocessed Herrin Coal, No Pretreatment............................... 35

17. Fixed Carbon Change in Herrin Coal, $\mathrm{CO}_{2} \ldots \ldots \ldots \ldots \ldots$

18. Fixed Carbon Change in Herrin Coal, $\mathrm{CO}_{2} /$ steam............ 37

19. Fixed Carbon Change in Pittsburgh No. 8 Coal, $\mathrm{CO}_{2} \ldots \ldots \ldots$

20. Fixed Carbon Change in Herrin Coal, No Pretreatment.......... 39

21. Properties of Liquid Products from Coprocessing.............40

22. Properties of Liquid Products from Coprocessing............ 41

23. Gas Analyses for Coprocessing Herrin Coal, $\mathrm{CO}_{2} \ldots \ldots \ldots \ldots$ 


\section{CONTENTS OF APPENDIX (continued)}

Table

Page

24. Gas Analyses for Coprocessing Herrin Coal, $\mathrm{CO}_{2} /$ steam......... 43

25. Gas Analyses for Coprocessing Pittsburgh No. 8 Coal, $\mathrm{CO}_{2} \ldots \ldots \ldots 4$

26. Gas Analyses for Coprocessing Herrin Coal, No Pretreatment..... 45 
Table 1. Analyses of Raw Coals

\begin{tabular}{|c|c|c|c|}
\hline & \multirow{2}{*}{$\begin{array}{l}\frac{\text { Herrin }}{\text { as }} \\
\text { received }\end{array}$} & \multicolumn{2}{|c|}{ Pittsburgh No. 8} \\
\hline & & $\begin{array}{l}\text { as } \\
\text { received }\end{array}$ & $\begin{array}{c}\text { air } \\
\text { dried }\end{array}$ \\
\hline \multicolumn{4}{|c|}{ Proximate, as received wt 8} \\
\hline $\begin{array}{l}\text { Moisture } \\
\text { Volatile Matter } \\
\text { Ash } \\
\text { Fixed Carbon }\end{array}$ & $\begin{array}{l}3.4 \\
36.6 \\
10.5 \\
49.5\end{array}$ & $\begin{array}{r}30.6 \\
23.7 \\
5.5 \\
40.2\end{array}$ & $\begin{array}{r}1.3 \\
33.0 \\
9.8 \\
56.0\end{array}$ \\
\hline \multicolumn{4}{|c|}{ Proximate, moisture free wt 8} \\
\hline $\begin{array}{l}\text { Volatile Matter } \\
\text { Ash } \\
\text { Fixed Carbon }\end{array}$ & $\begin{array}{l}37.9 \\
10.9 \\
51.2\end{array}$ & $\begin{array}{r}34.1 \\
7.9 \\
57.9\end{array}$ & $\begin{array}{r}33.4 \\
9.9 \\
56.7\end{array}$ \\
\hline \multicolumn{4}{|c|}{ Ultimate, moisture free wt 8} \\
\hline $\begin{array}{l}\text { Carbon } \\
\text { Hydrogen } \\
\text { Nitrogen } \\
\text { sulfur } \\
\text { oxygen (diff) }\end{array}$ & $\begin{array}{r}66.3 \\
4.7 \\
1.2 \\
3.6 \\
13.3\end{array}$ & $\begin{array}{r}64.3 \\
5.4 \\
1.2 \\
1.3 \\
19.9\end{array}$ & $\begin{array}{r}74.7 \\
4.9 \\
1.4 \\
1.4 \\
7.7\end{array}$ \\
\hline $\begin{array}{l}\text { Heating value } \\
(B t u / 1 b)\end{array}$ & 11,771 & & 13,343 \\
\hline \multicolumn{4}{|l|}{ Fischer Assay, wt 8} \\
\hline $\begin{array}{l}\text { Oil } \\
\text { Water } \\
\text { Gas }\end{array}$ & $\begin{array}{c}13.53 \\
10.69 \\
6.99\end{array}$ & & $\begin{array}{c}13.55 \\
4.72 \\
5.53\end{array}$ \\
\hline spent Coal & 68.79 & & 76.19 \\
\hline
\end{tabular}


Table 2. Screen Analyses for Raw Feed Coal, wt \& Retained

\begin{tabular}{rrr}
$\begin{array}{c}\text { Screen Size } \\
\text { Mesh }\end{array}$ & Herrin & Pittsburgh No.8 \\
\hline 16 & 0.00 & 1.60 \\
28 & 6.40 & 12.60 \\
32 & 13.50 & 10.60 \\
42 & 18.40 & 12.60 \\
60 & 17.00 & 12.70 \\
70 & 6.60 & 6.20 \\
100 & 11.00 & 10.40 \\
150 & 8.50 & 7.20 \\
200 & 2.60 & 4.10 \\
pan & 16.00 & 22.00 \\
\hline
\end{tabular}

U.S. Standard sieves 
Proximate, as received wt 8

Moisture

Volatile Matter

Ash

Fixed Carbon

Proximate, moisture free wt 8

Volatile Matter

Ash

Fixed Carbon

Ultimate, moisture free wt \&

$$
\begin{array}{r}
12.99 \\
86.96 \\
.01 \\
.04
\end{array}
$$

99.94

0.01

0.05

80.7

8.1

0.9

0.6

9.7

oxygen (diff)

Solubility Profile, wt 8

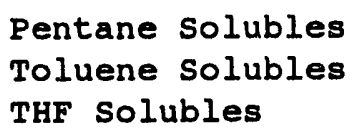

Residuum

Specific Gravity

$$
\begin{aligned}
& 61.8 \\
& 29.2 \\
& 8.4 \\
& 0.6 \\
& 1.0427
\end{aligned}
$$

Distillation Profile, wt 8

(Pentane solubles)

$\begin{array}{lr}I B P-300^{\circ} \mathrm{F} & 2.2 \\ 300-500^{\circ} \mathrm{F} & 27.4 \\ 500-700^{\circ} \mathrm{F} & 31.0 \\ 700-1000^{\circ} \mathrm{F} & 32.0 \\ >1000^{\circ} \mathrm{F} & 7.5\end{array}$


Table 4. Pretreatment Test Conditions

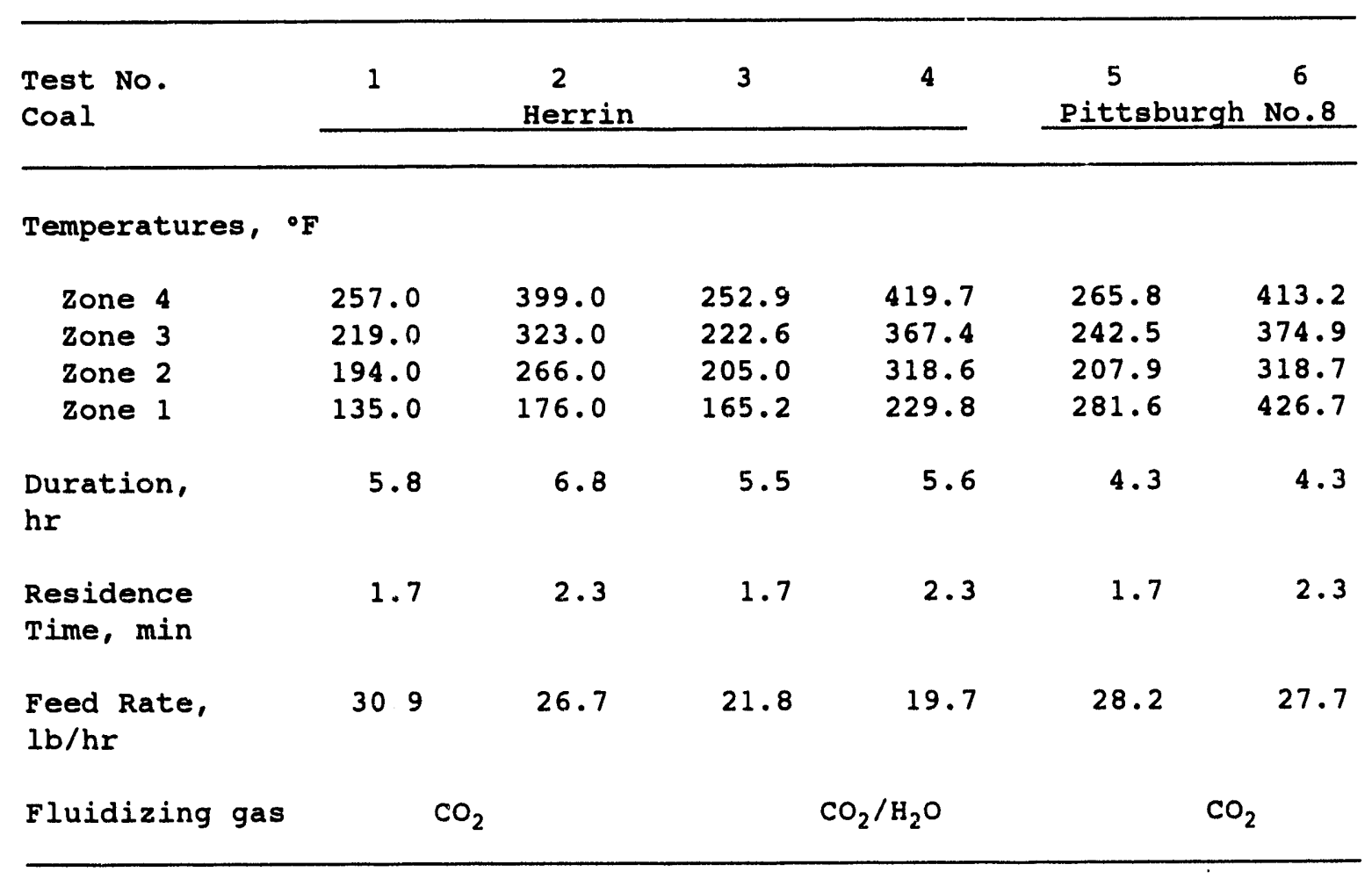




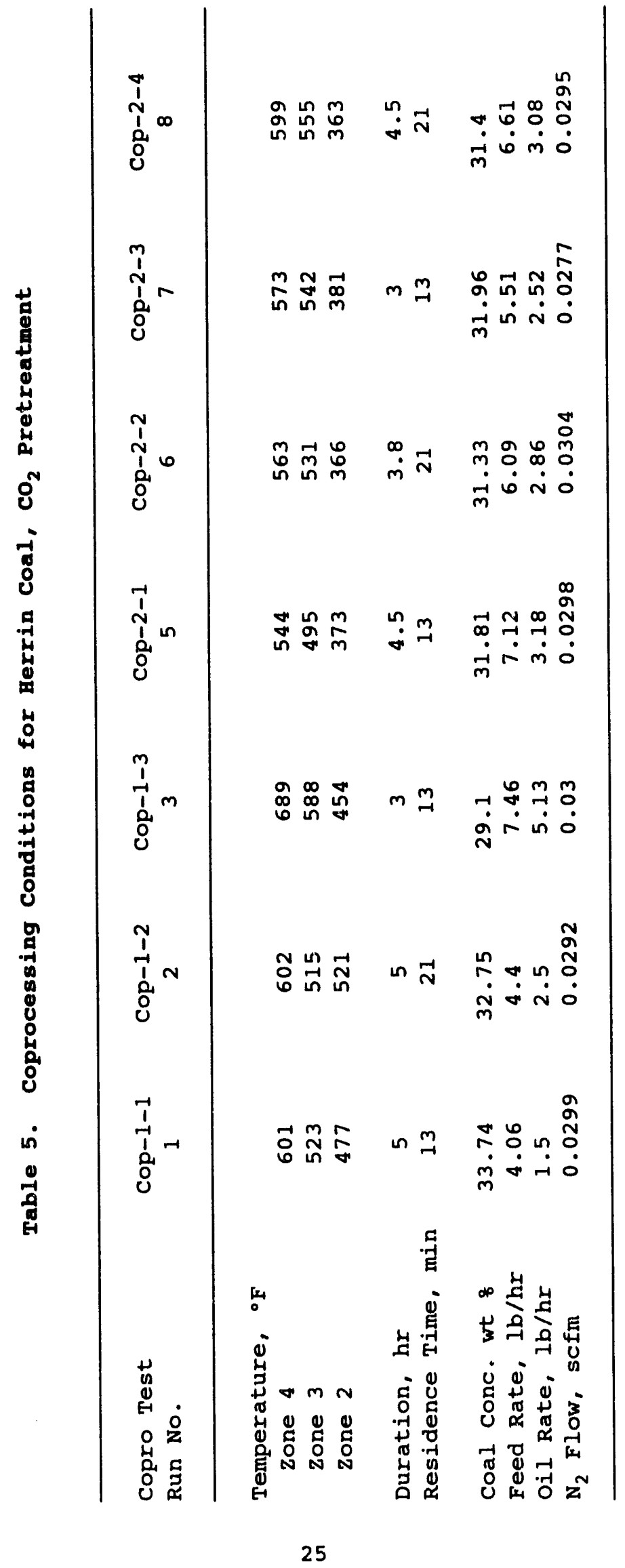




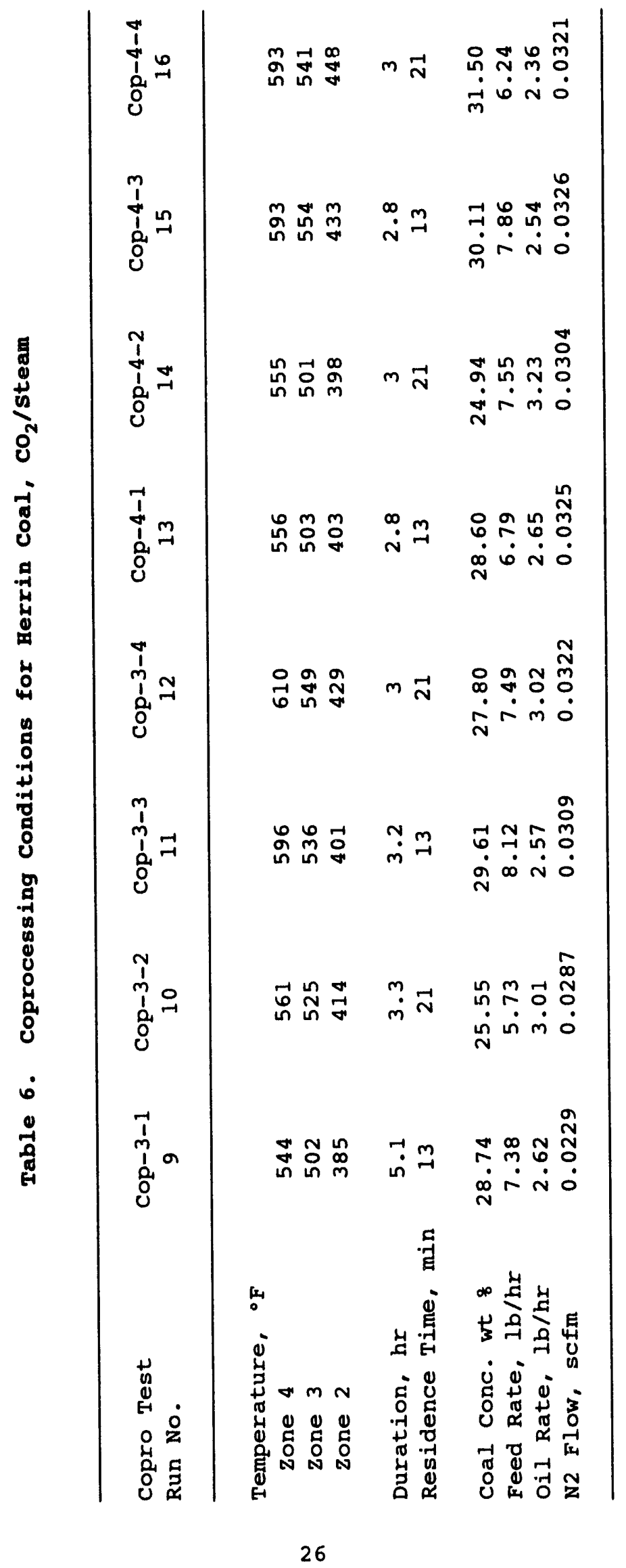




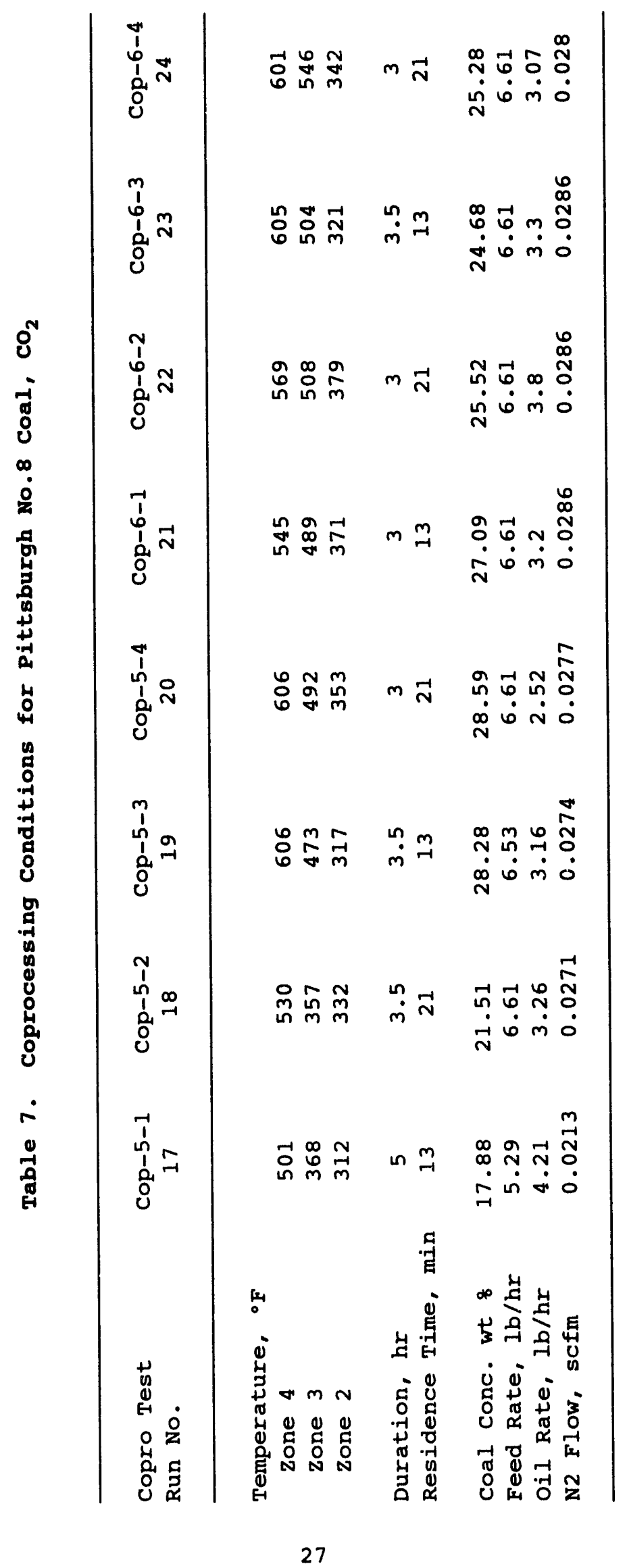


Table 8. Coprocessing Conditions for Herrin Coal, No Pretreatment

\begin{tabular}{lccc}
\hline $\begin{array}{l}\text { Copro Test } \\
\text { Run No. }\end{array}$ & $\begin{array}{c}\text { Cop-7-1 } \\
25\end{array}$ & $\begin{array}{c}\text { Cop-7-2 } \\
26\end{array}$ & 28 \\
\hline $\begin{array}{l}\text { Temperature, }{ }^{\circ} \mathrm{F} \\
\text { Zone 4 } \\
\text { Zone 3 }\end{array}$ & 556 & 575 & 602 \\
Zone 2 & 505 & 542 & 572 \\
& 303 & 329 & 357 \\
Duration, hr & 5.8 & 3 & 3 \\
Residence Time, min & 13 & 21 & 21 \\
Coal Conc. wt 8 & 34.33 & 34.16 & 20.59 \\
Feed Rate, lb/hr & 6.69 & 6.61 & 5.5 \\
Oil Rate, lb/hr & 3.66 & 3.07 & 6.3 \\
N2 Flow, scfm & 0.298 & 0.0315 & 0.0297 \\
\hline
\end{tabular}

Table 9. Material Balances for Pretreatment Tests

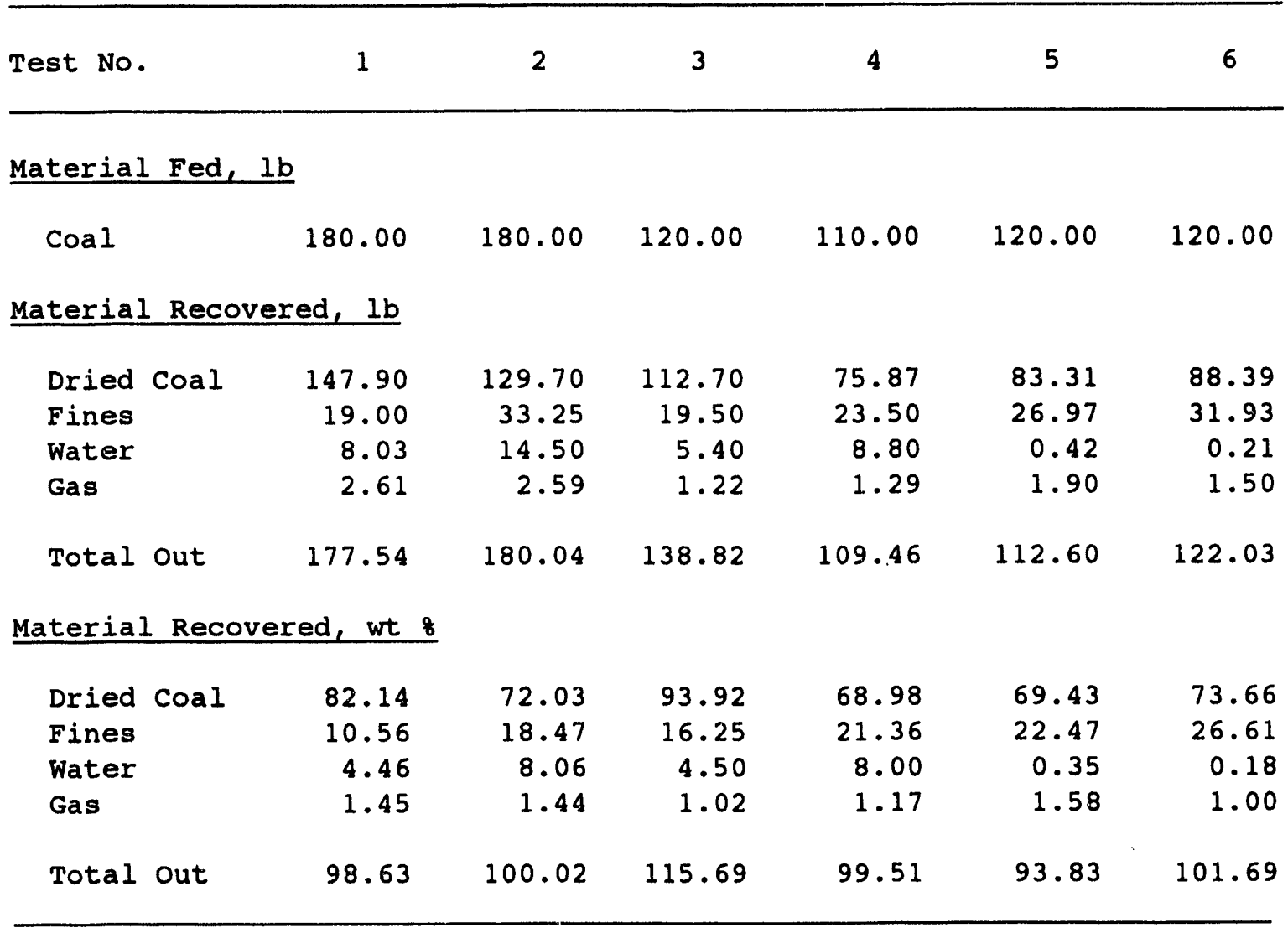


Table 10. Product Analyses for Pretreatment Tests on Herrin Coal

\begin{tabular}{|c|c|c|c|c|c|}
\hline Run No. & Raw Coal & 1 & 2 & 3 & 4 \\
\hline \multicolumn{6}{|c|}{ Proximate, as received wt 8} \\
\hline Moisture & 3.4 & 2.5 & 0.3 & 2.2 & 0.8 \\
\hline Volatile Matter & 36.6 & 37.1 & 38.4 & 38.7 & 39.0 \\
\hline Ash & 10.5 & 11.2 & 10.9 & 11.0 & 11.2 \\
\hline Fixed Carbon & 49.5 & 49.1 & 50.4 & 47.7 & 49.0 \\
\hline \multicolumn{6}{|c|}{ Proximate, moisture free wt 8} \\
\hline Volatile Matter & 37.9 & 38.1 & 38.5 & 39.6 & 39.3 \\
\hline Ash & 10.9 & 11.5 & 10.9 & 11.2 & 11.3 \\
\hline Fixed Carbon & 51.2 & 50.4 & 50.6 & 48.8 & 49.4 \\
\hline \multicolumn{6}{|c|}{ Ultimate, moisture free wt of } \\
\hline Carbon & 66.3 & 69.0 & 69.4 & 68.2 & 67.6 \\
\hline Hydrogen & 4.7 & 5.0 & 4.9 & 5.1 & 4.8 \\
\hline Nitrogen & 1.2 & 1.2 & 1.2 & 1.3 & 1.2 \\
\hline sulfur & 3.6 & 3.5 & 3.8 & 4.7 & 3.5 \\
\hline oxygen (diff) & 13.3 & 9.8 & 9.8 & 9.5 & 11.6 \\
\hline $\begin{array}{l}\text { Heating Value } \\
\text { (Btu/lb) }\end{array}$ & 11,771 & 11,823 & 12,642 & 12,063 & 12,532 \\
\hline \multicolumn{6}{|l|}{ Fischer Assay, wt 8} \\
\hline oil & 13.73 & 13.10 & 14.09 & 14.90 & 13.60 \\
\hline Water & 10.66 & 7.92 & 5.93 & 8.44 & 6.94 \\
\hline Gas & 6.90 & 7.58 & 7.46 & 7.53 & 7.48 \\
\hline spent Coal & 68.71 & 71.40 & 72.53 & 69.14 & 71.97 \\
\hline Pretreatment Temp. & - & 257 & 399 & 253 & 420 \\
\hline
\end{tabular}


Table 11. Product Analyses for Pretreatment Tests on Pittsburgh No.8 Coal

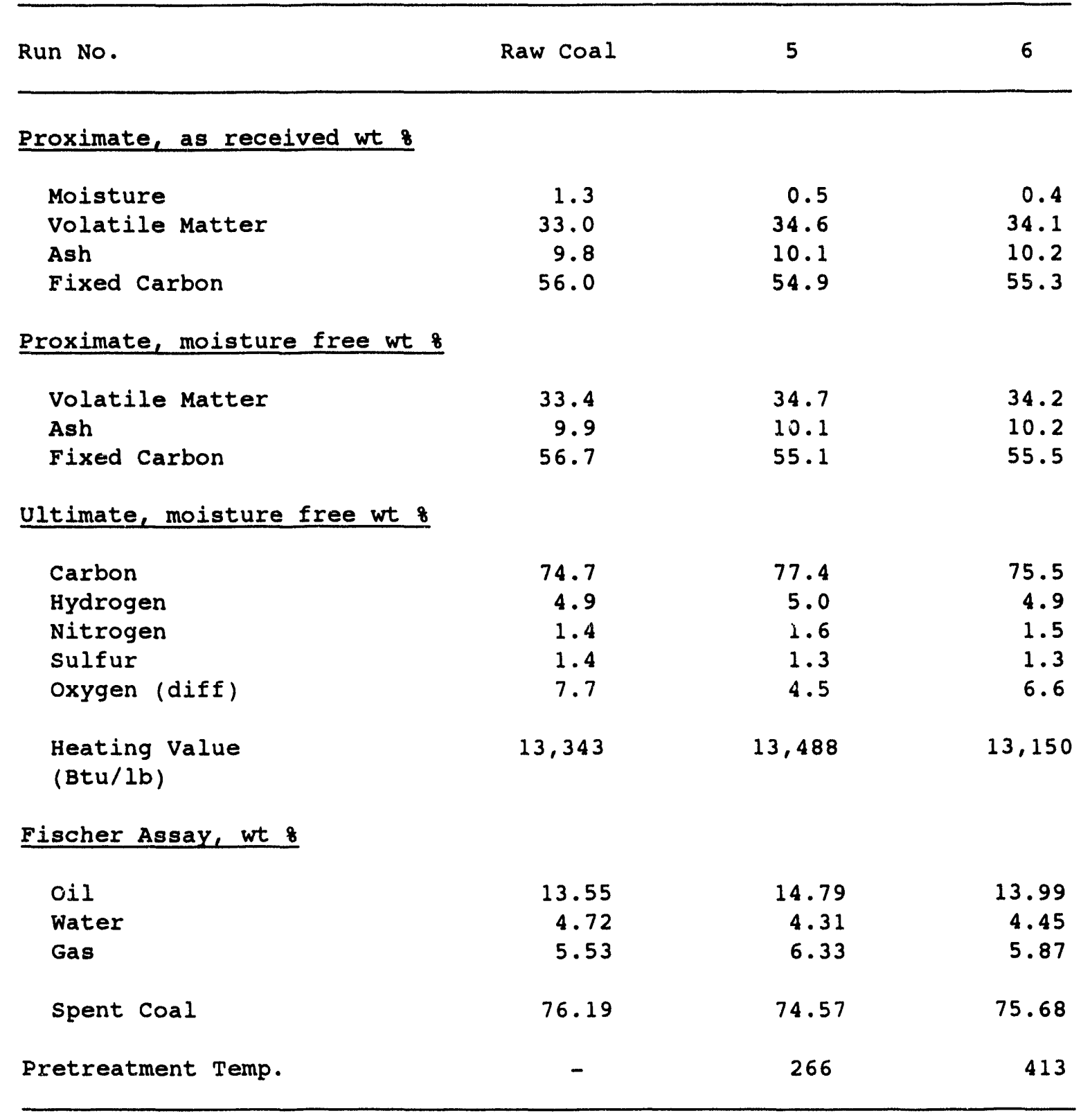




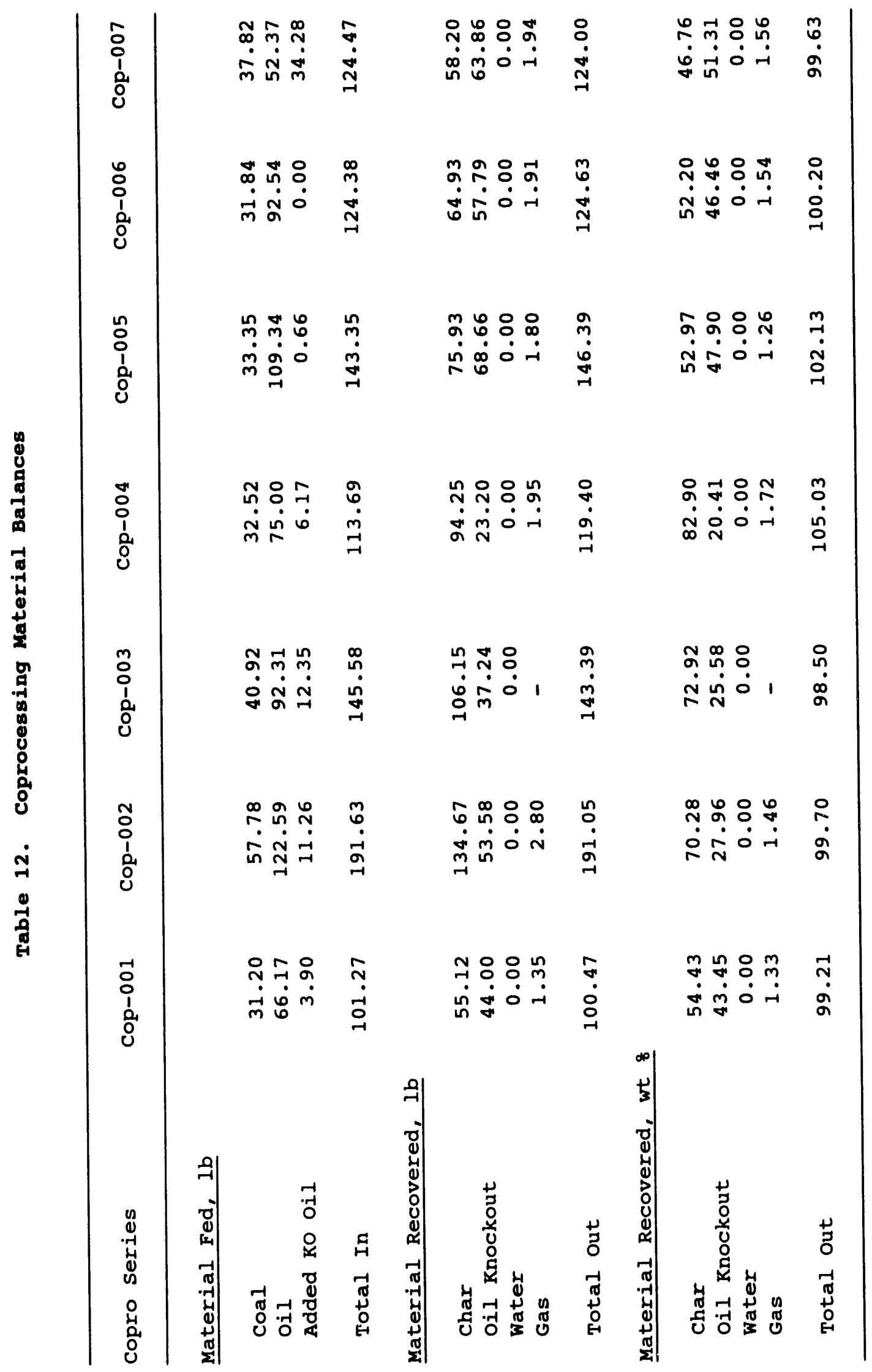




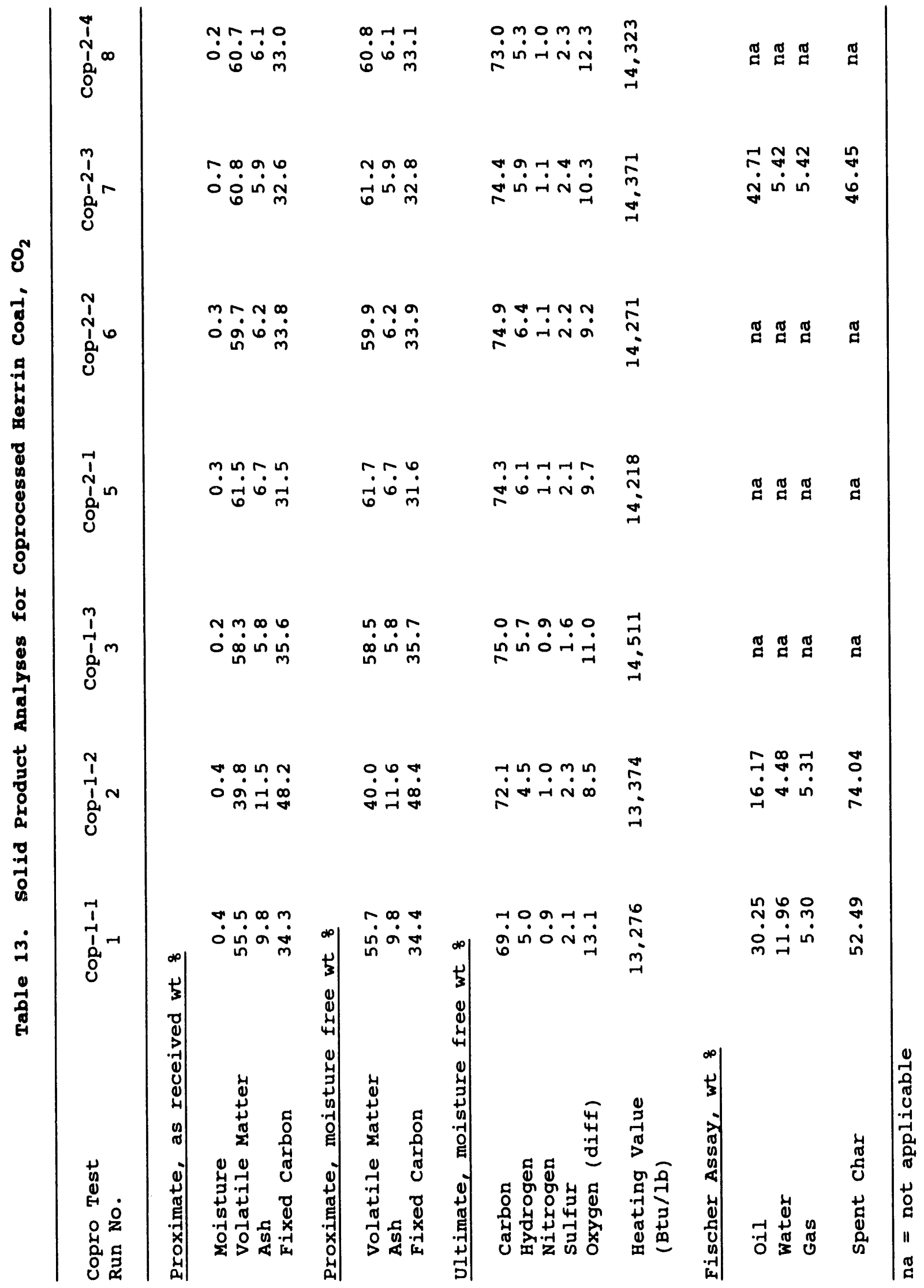




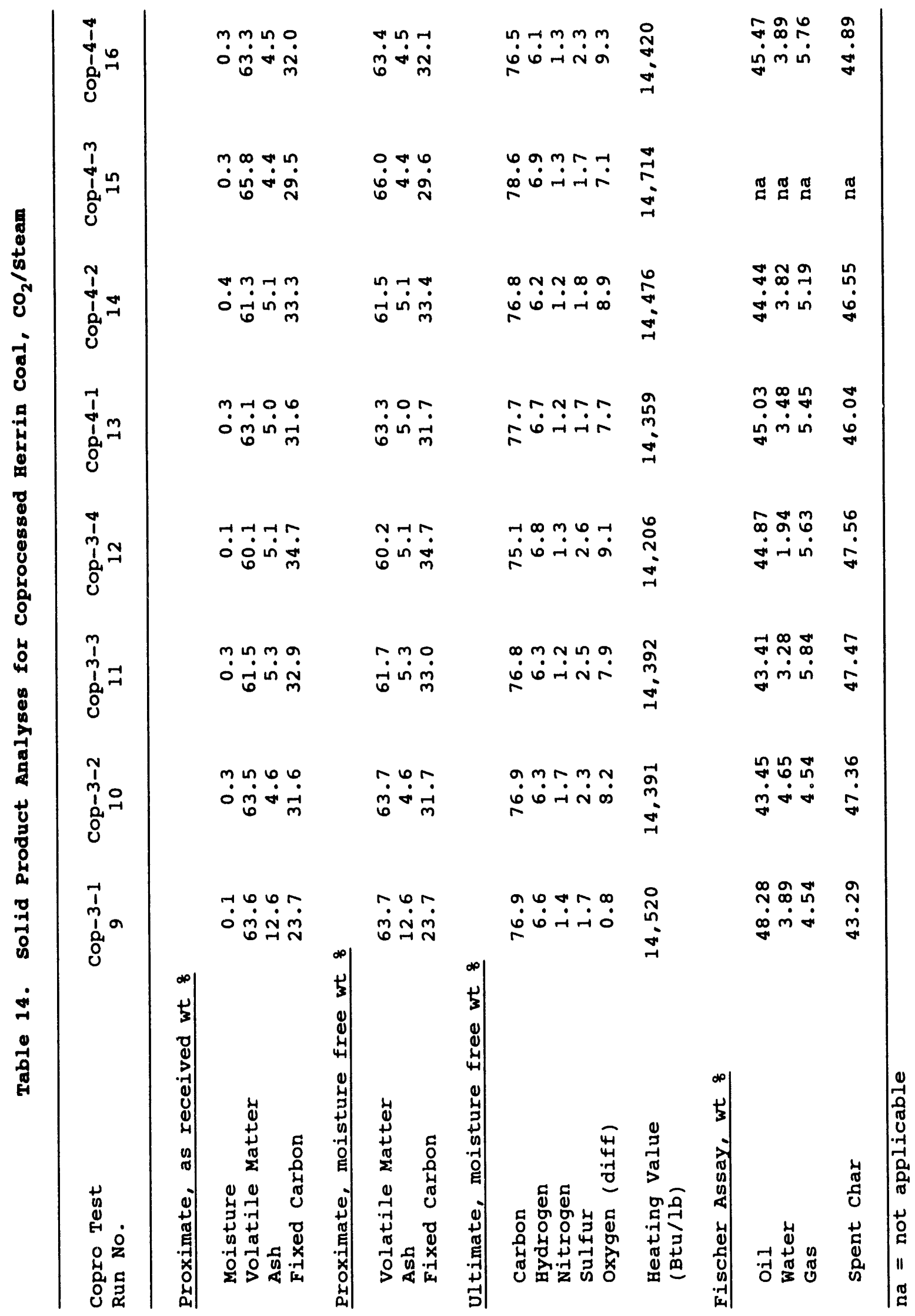




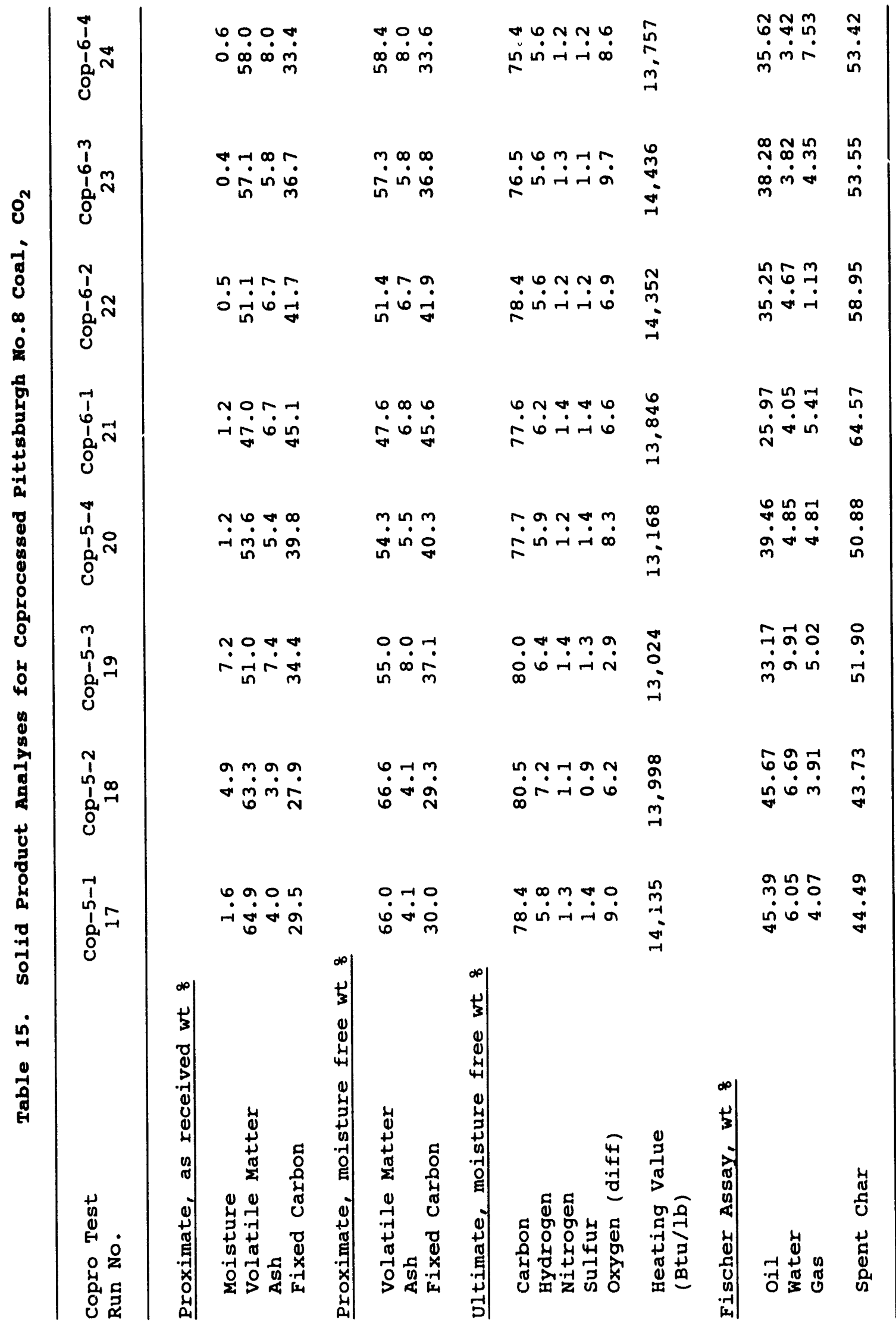


Table 16. Solid Product Analyses for Coprocessed Herrin Coal, No Pretreatment

\begin{tabular}{lccc}
\hline Copro Test & Cop-7-1 & Cop-7-2 & Cop-7-4 \\
Run No. & 25 & 26 & 28 \\
\hline
\end{tabular}

Proximate, as received wt 8

$\begin{array}{lrrr}\text { Moisture } & 1.3 & 1.2 & 13.6 \\ \text { Volatile Matter } & 50.7 & 45.0 & 44.0 \\ \text { Ash } & 8.8 & 10.1 & 8.0 \\ \text { Fixed Carbon } & 39.2 & 43.7 & 34.5\end{array}$

Proximate, moisture free wt 8

$\begin{array}{lrrr}\text { Volatile Matter } & 51.4 & 45.5 & 50.9 \\ \text { Ash } & 8.9 & 10.2 & 9.2 \\ \text { Fixed Carbon } & 39.7 & 44.2 & 39.9\end{array}$

Ulimate, moisture free wt 8

$\begin{array}{lrrr}\text { Carbon } & 71.1 & 70.7 & 76.6 \\ \text { Hydrogen } & 6.0 & 5.9 & 6.9 \\ \text { Nitrogen } & 1.2 & 1.1 & 1.3 \\ \text { Sulfur } & 2.6 & 3.8 & 3.3 \\ \text { Oxygen (diff) } & 10.2 & 8.3 & 2.7 \\ \text { Heating Value } & 13,173 & 12,955 & 11,583 \\ \text { (Btu/1b) } & & & \end{array}$

Fischer Assay, wt 8

\begin{tabular}{lrrr} 
Oil & 32.00 & 24.91 & 26.95 \\
Water & 6.11 & 5.73 & 16.41 \\
Gas & 5.42 & 6.52 & 4.72 \\
Spent Char & & & \\
& 56.47 & 62.84 & 51.92 \\
\hline
\end{tabular}




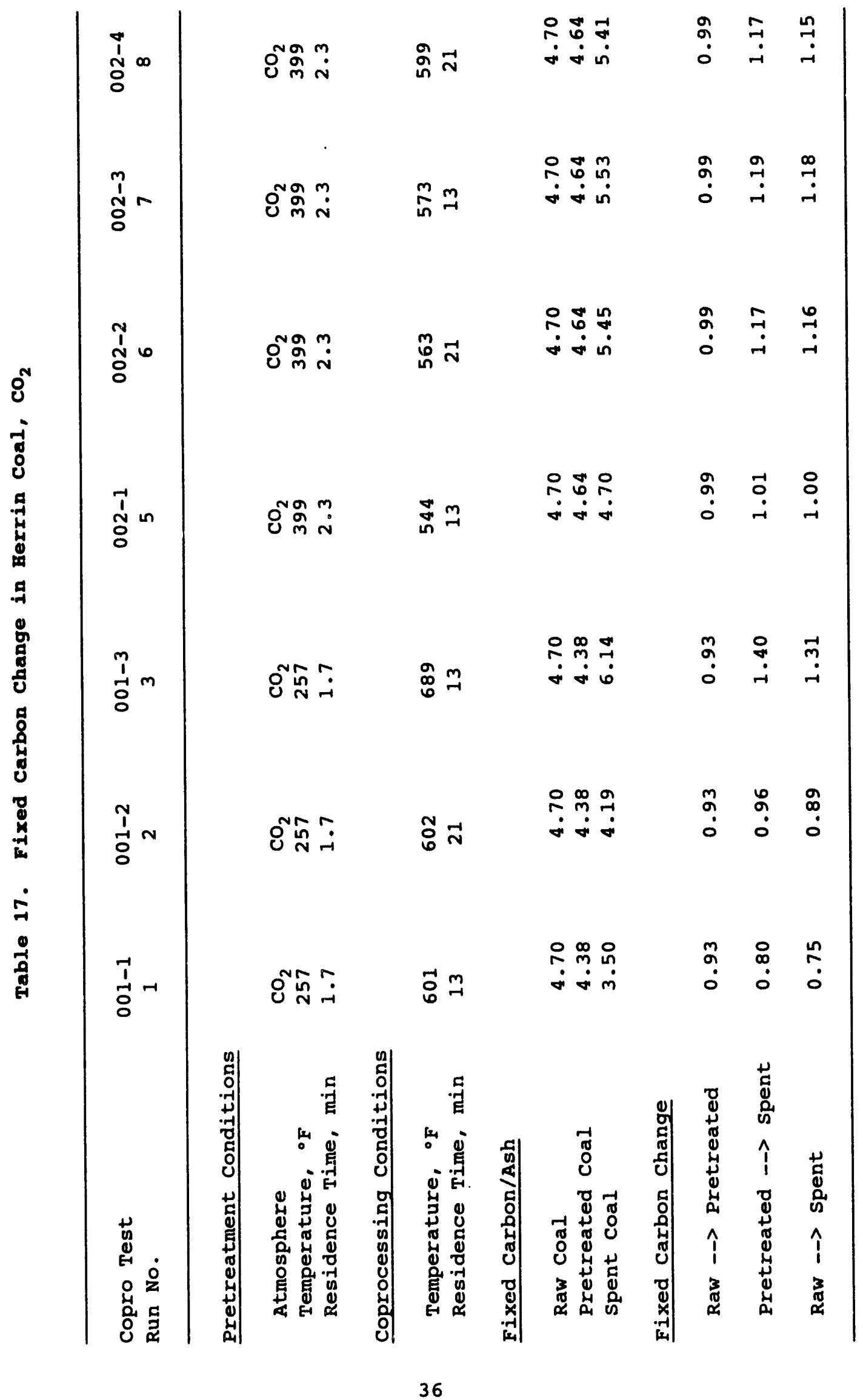




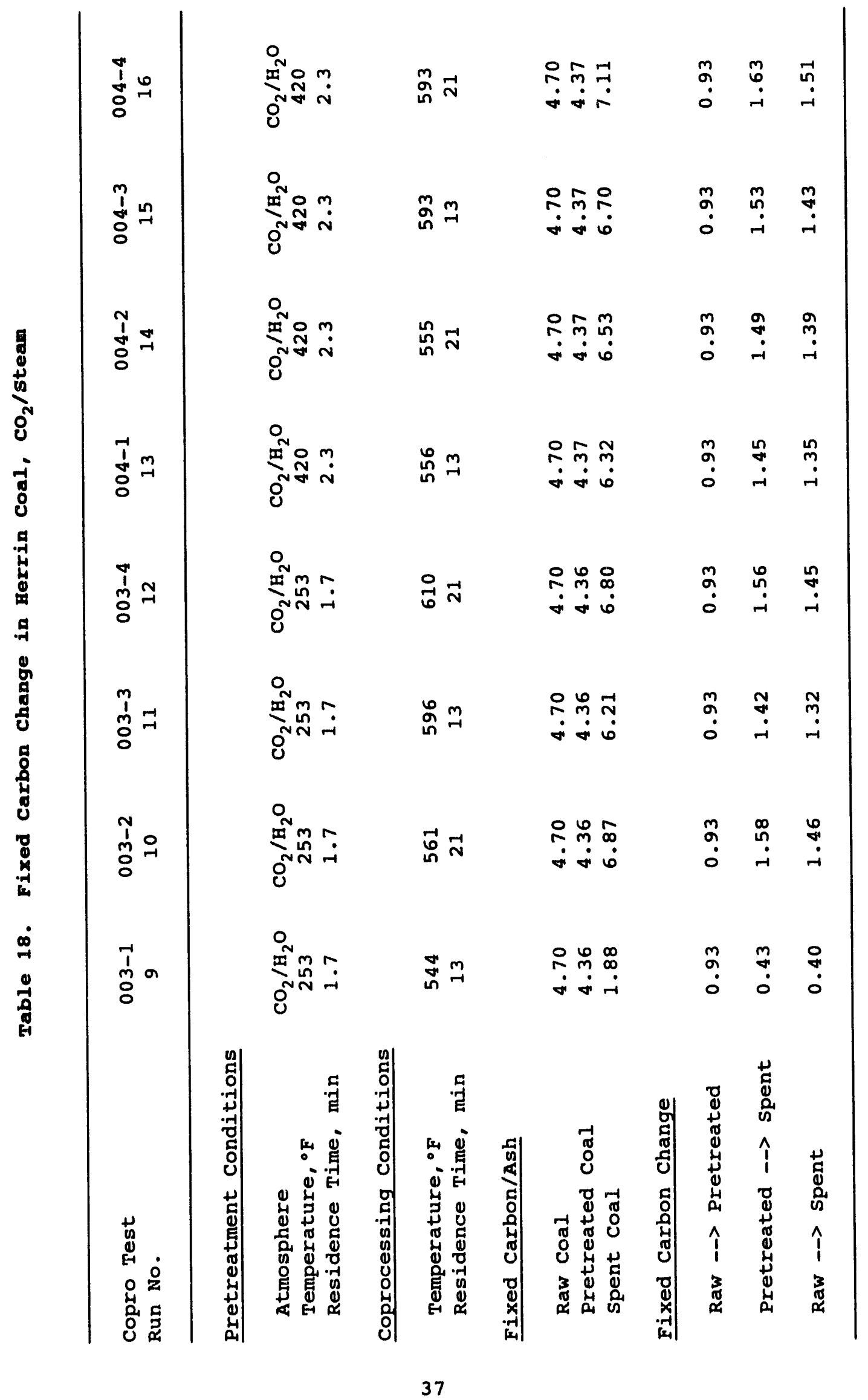




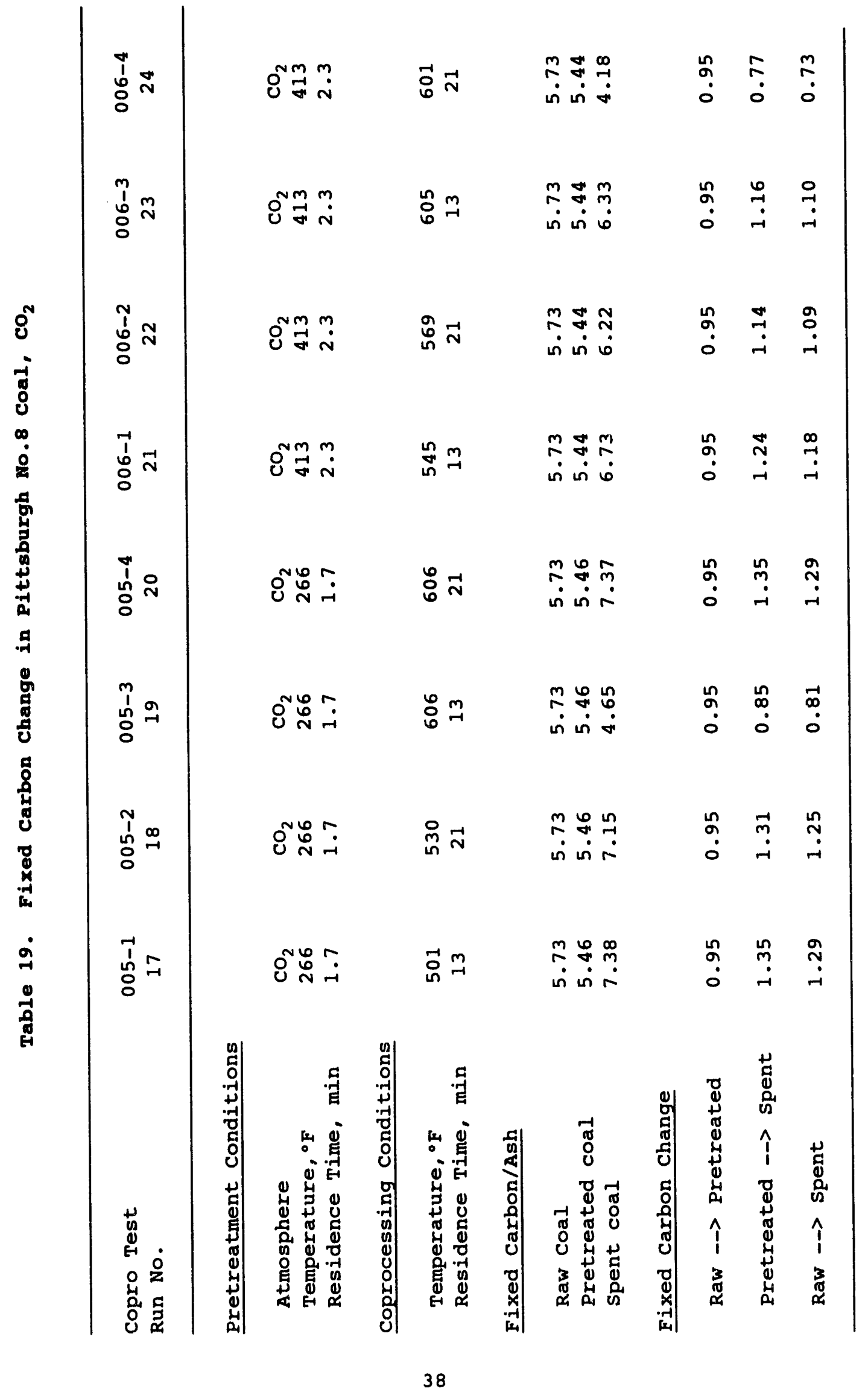


Table 20. Fixed Carbon Change in Berrin Coal, No Pretreatment

\begin{tabular}{|c|c|c|c|}
\hline $\begin{array}{l}\text { Copro Test } \\
\text { Run No. }\end{array}$ & $\begin{array}{c}007-1 \\
25\end{array}$ & $\begin{array}{c}007-2 \\
26\end{array}$ & $\begin{array}{c}007-4 \\
28\end{array}$ \\
\hline \multicolumn{4}{|l|}{ Coprocessing Conditions } \\
\hline $\begin{array}{l}\text { Temperature, }{ }^{\circ} \mathrm{F} \\
\text { Residence Time, min }\end{array}$ & $\begin{array}{c}556 \\
13\end{array}$ & $\begin{array}{c}575 \\
21\end{array}$ & $\begin{array}{c}602 \\
21\end{array}$ \\
\hline \multicolumn{4}{|l|}{ Fixed Carbon/Ash } \\
\hline Raw Coal & 4.70 & 4.70 & 4.70 \\
\hline Spent Coal & 4.45 & 4.33 & 4.31 \\
\hline \multicolumn{4}{|l|}{ Fixed Carbon Change } \\
\hline Raw $-\rightarrow$ spent & 0.95 & 0.92 & 0.92 \\
\hline
\end{tabular}




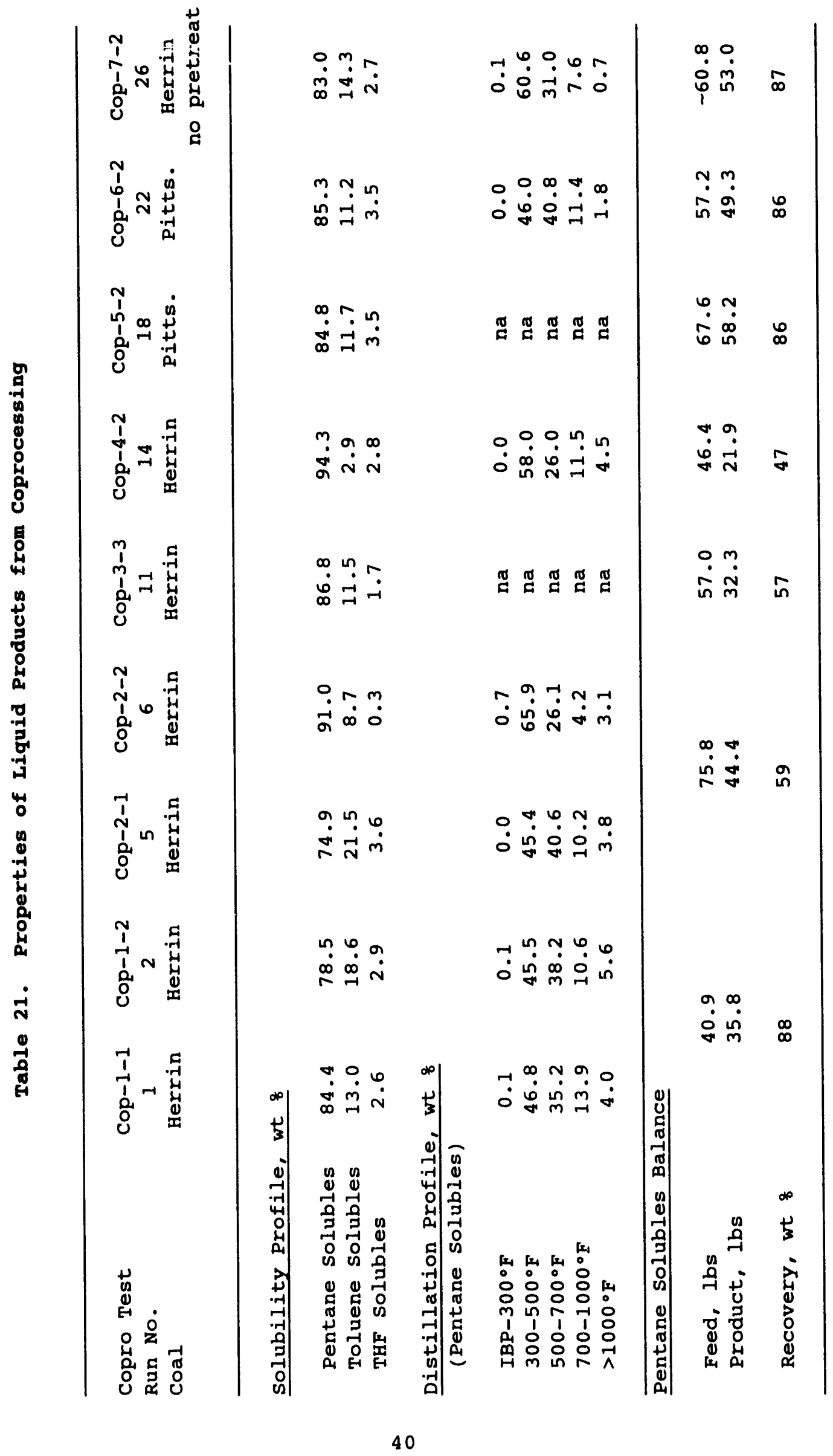




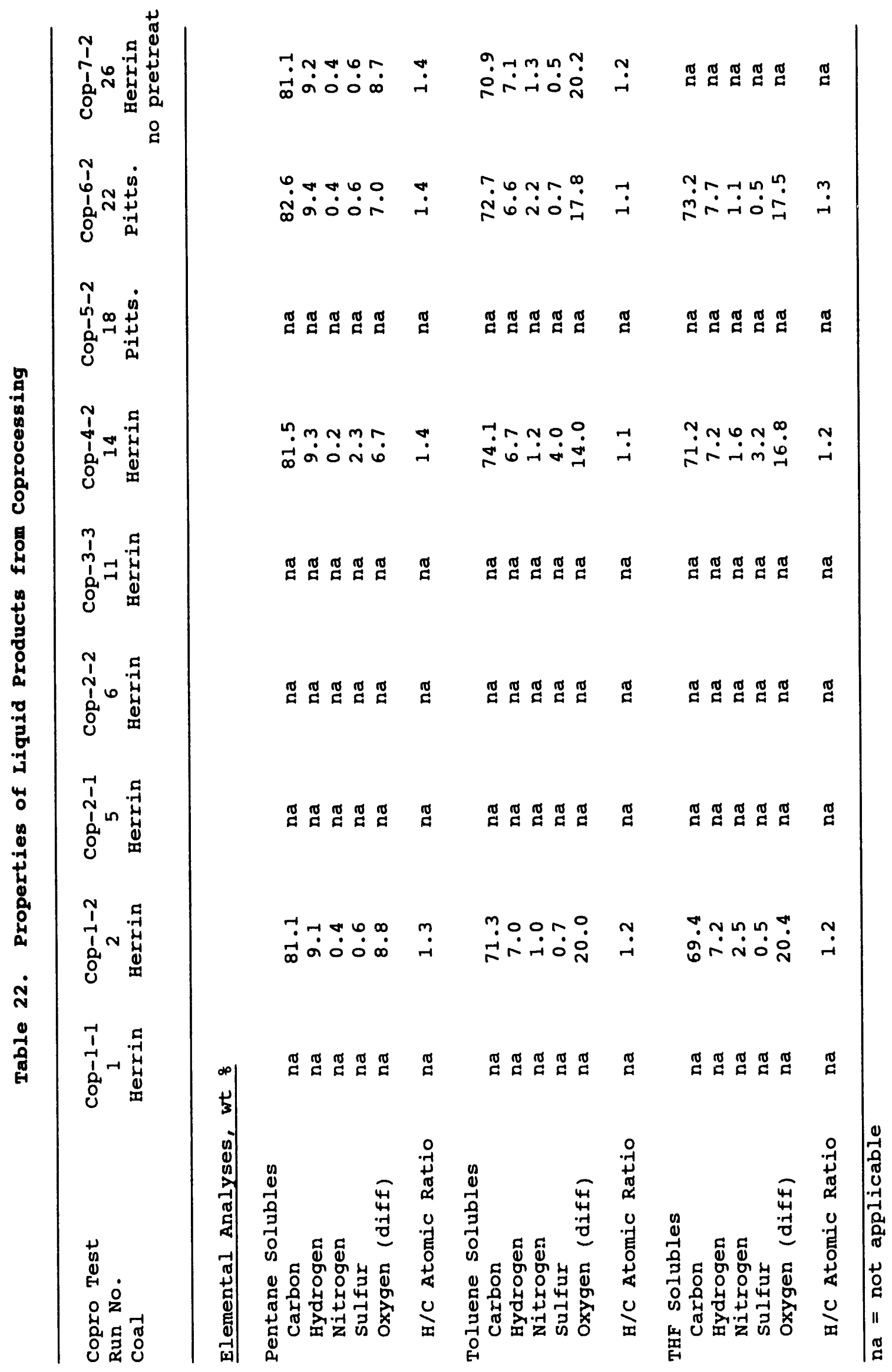




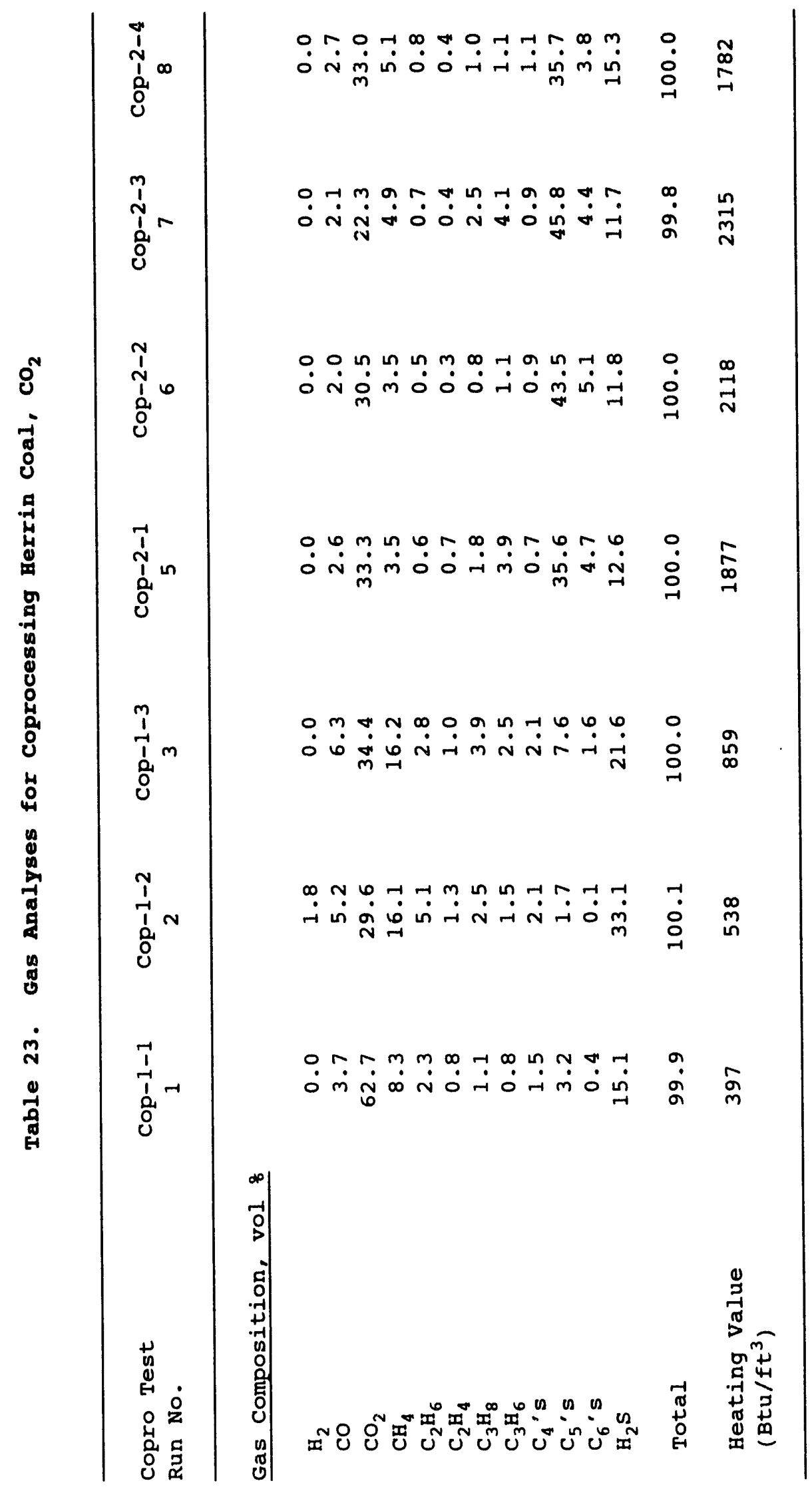




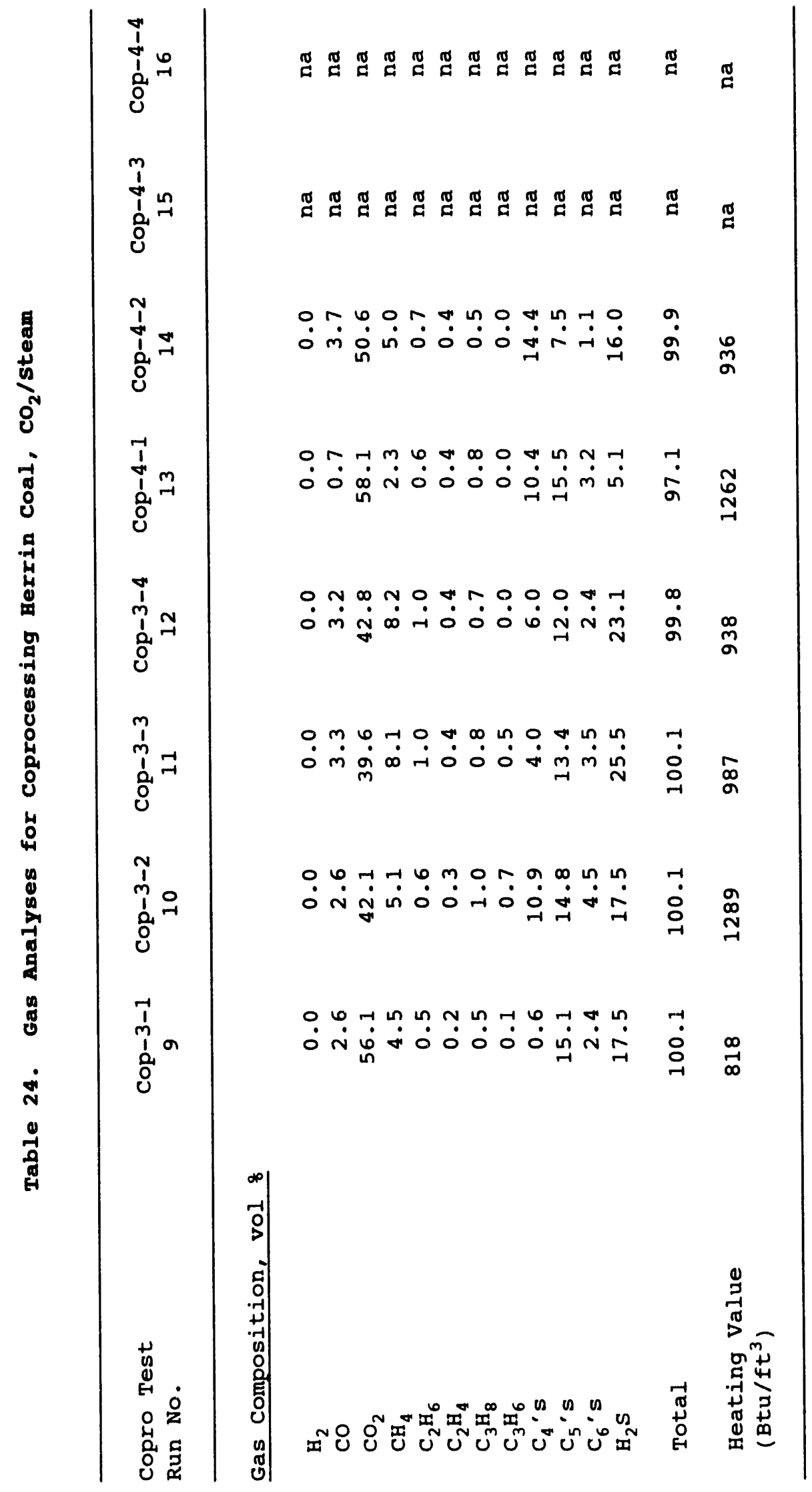







Table 26. Gas Analyses for Coprocessing, Herrin Coal, No Pretreatment

\begin{tabular}{|c|c|c|c|}
\hline $\begin{array}{l}\text { Copro Test } \\
\text { Run No. }\end{array}$ & $\begin{array}{c}\text { Cop-7-1 } \\
25\end{array}$ & $\begin{array}{c}\text { Cop-7-2 } \\
26\end{array}$ & $\begin{array}{c}\text { Cop-7-4 } \\
28\end{array}$ \\
\hline \multicolumn{4}{|c|}{ Gas Composition, vol 8} \\
\hline $\mathrm{H}_{2}$ & 0.0 & 0.0 & 0.0 \\
\hline co & 2.7 & 3.4 & 3.1 \\
\hline $\mathrm{CO}_{2}$ & 55.9 & 44.3 & 42.4 \\
\hline $\mathrm{CH}_{4}$ & 2.8 & 2.9 & 4.2 \\
\hline $\mathrm{C}_{2} \mathrm{H}_{6}$ & 0.2 & 0.3 & 0.7 \\
\hline $\mathrm{C}_{2} \mathrm{H}_{4}$ & 0.1 & 0.2 & 0.5 \\
\hline $\mathrm{C}_{3} \mathrm{H}_{8}$ & 0.8 & 4.2 & 8.4 \\
\hline $\mathrm{C}_{3} \mathrm{H}_{6}$ & 0.0 & 0.0 & 0.0 \\
\hline $\mathrm{C}_{4}^{\prime} \mathrm{s}$ & 11.7 & 14.0 & 19.4 \\
\hline$c_{5}^{\prime} s$ & 12.3 & 17.3 & 7.8 \\
\hline$C_{6}^{\prime} s$ & 3.1 & 4.6 & 4.1 \\
\hline $\mathrm{H}_{2} \mathrm{~S}$ & 10.4 & 8.9 & 9.4 \\
\hline Total & 100.0 & 100.0 & 100.0 \\
\hline $\begin{array}{l}\text { Heating Value } \\
(\text { Btu/ft })\end{array}$ & 1096 & 1538 & 1448 \\
\hline
\end{tabular}



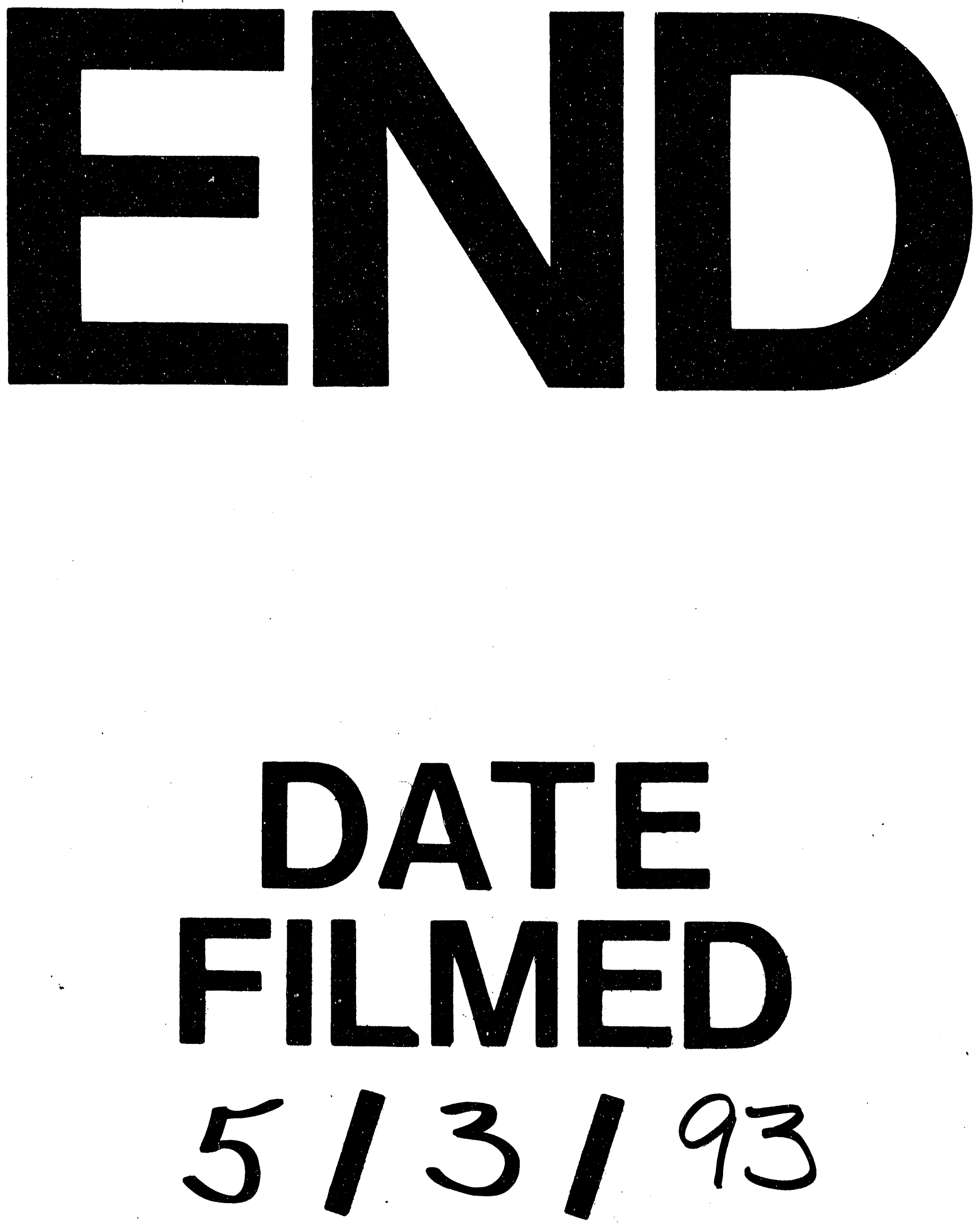
